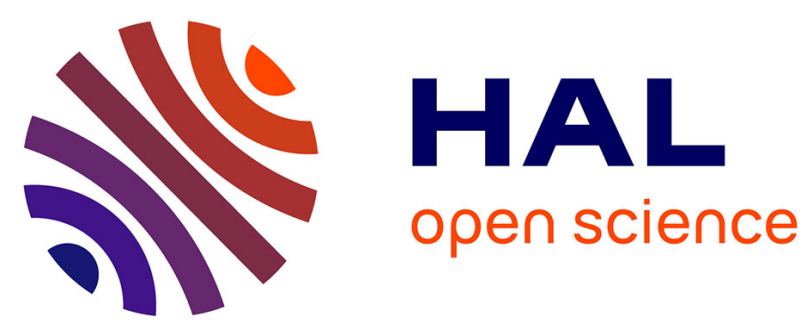

\title{
Could deep subantarctic convection feed the world deep basins during the Last Glacial Maximum?
}

Elisabeth Michel, Laurent Labeyrie, Jean-Claude Duplessy, Nabila Gorfti, Monique Labracherie, Jean-Louis Turon

\section{- To cite this version:}

Elisabeth Michel, Laurent Labeyrie, Jean-Claude Duplessy, Nabila Gorfti, Monique Labracherie, et al. Could deep subantarctic convection feed the world deep basins during the Last Glacial Maximum? Paleoceanography, 1995, 10 (5), pp.927-941. 10.1029/95PA00978 . hal-02913417

\section{HAL Id: hal-02913417 https://hal.science/hal-02913417}

Submitted on 3 Feb 2021

HAL is a multi-disciplinary open access archive for the deposit and dissemination of scientific research documents, whether they are published or not. The documents may come from teaching and research institutions in France or abroad, or from public or private research centers.
L'archive ouverte pluridisciplinaire HAL, est destinée au dépôt et à la diffusion de documents scientifiques de niveau recherche, publiés ou non, émanant des établissements d'enseignement et de recherche français ou étrangers, des laboratoires publics ou privés. 


\title{
Could deep Subantarctic convection feed the world deep basins during the last glacial maximum?
}

\author{
Elisabeth Michel, Laurent D. Labeyrie, Jean-Claude Duplessy, and Nabila Gorfti \\ Centre des Faibles Radioactivités, Laboratoire mixte CNRS-CEA, Gif-sur-Yvette, France
}

\section{Monique Labracherie and Jean-Louis Turon}

Département de Géologie et d'Océanographie, Université Bordeaux, Talence, France

\begin{abstract}
Simple box model calculations are used to simulate the oceanic circulation during the last glacial maximum (LGM). These experiments show that the main features of the $\delta^{13} \mathrm{C}$ and $\Delta^{14} \mathrm{C}$ distributions and of the lysocline depth may be explained by a circulation pattern very different from the modern one. Intermediate and upper deep waters were produced in the North Atlantic Ocean, whereas deep waters of Subantarctic Mode type, forming at the northern edge of the Subantarctic convergence, invaded the main oceanic basins. The Southern Ocean, mainly self ventilated, had a reduced deep component that flew southward along the East Pacific Ridge and the Australian west cost. The thermodynamic fractionation that occurs during air-sea exchange has only contributed slightly to the glacial deep $\delta^{13} \mathrm{C}$ distribution through surface water temperature variations.
\end{abstract}

\section{Introduction}

Isotopic records of foraminifera tell us that during the last glacial maximim (LGM), ocean circulation was rather different from the modern. During glacials, intermediate and upper deep waters (down to $2000 \mathrm{~m}$ ) were formed in the North Atlantic instead of North Atlantic Deep Water (NADW). This produced an intermediate water enrichment in ${ }^{13} \mathrm{C}$ [Boyle and Keigwin, 1987; Duplessy et al., 1988]. North of $40^{\circ} \mathrm{N}$, deep water had $\delta^{13} \mathrm{C}$ values of about $1 \%$, indicating that significant ventilation did occur [Charles and Fairbanks, 1992; Duplessy et al., 1988; Keir, 1988; Oppo and Fairbanks, 1987]. However, at lower latitude, ${ }^{13} \mathrm{C}$-poor deep waters replaced the ventilated NADW. The low $\delta^{13} \mathrm{C}$ values of Atlantic deep waters have been attributed to an enhanced influence of the Antarctic Bottom Water (AABW). As in the modern, there was no deep water formation in the North Pacific [Keigwin, 1987].

An increase of the AABW flow does not explain a puzzling feature: the Southern Ocean $\delta^{13} \mathrm{C}$ values were significantly lower than Pacific ones during oxygen isotopic chronozone 2. In order to explain this, Mackensen et al. [1993] proposed that the values of $C$. wuellerstorfi living south of the polar front are not representative of the total dissolved inorganic carbon isotopic composition. However, this hypothesis is not sufficient alone to exclude an oceanographic explanation for the $\delta^{13} \mathrm{C}$ values of the Southern Ocean because low values have also been measured on different types of benthic foraminifera (Nonion and Uvigerina) for the LGM. The low $\delta^{13} \mathrm{C}$ values of benthic foraminifera need then to be considered as representative of the total dissolved inorganic carbon $\delta^{13} \mathrm{C}$ value of the Southern Ocean waters. A major drop of benthic foraminifera $\delta^{13} \mathrm{C}$ during LGM is supported by a similar drop in the planktonic record [Labeyrie and Duplessy, 1985;

Copyright 1995 by the American Geophysical Union.

Paper number 95PA00978.

0883-8305/95/95PA-00978\$10.00
Charles and Fairbanks, 1990; Mortlock et al., 1991]. We shall explore the cause of this drop which may be due either to thermodynamic fractionation [Broecker, 1993] or to a very different circulation pattern. The Pacific Ocean, which showed higher $\delta^{13} \mathrm{C}$ values than Southern Ocean values, could not be filled by a deep water originated in the Southern Ocean; another source is to be found to feed the Pacific basin during the LGM.

The aim of this paper is to show that the LGM $\delta^{13} \mathrm{C}$ distribution may be explained by a different ocean circulation. We used for this study a geochemical box model of PandoraCyclops type [Broecker and Peng, 1986; Keir, 1988]. This circulation implies that the deep waters which filled the Atlantic, Indian and Pacific basins were of Subantarctic Mode water type, formed along the Subantarctic convergence and flowing northward.

\section{Model Description}

We tested first the model on the modern ocean circulation and then used it to simulate the glacial type circulation.

Model boxes represent the major water masses. They are presented on Figure 1 (modern reference), with the modern advective and diffusive fluxes. The Atlantic and Pacific Oceans show very different thermohaline circulation and chemical characteristics, and we know from the data that they had their own particular histories during the past. The structure of the box model displays two separate oceans, one representing the Atlantic Ocean, the other the Indian and Pacific Oceans. These two basins have deep, intermediate, and surface water boxes. For the surface boxes, we distinguish the equatorial zone, where strong upwellings occur, from midlatitude boxes, representing gyre zones. The model contains north and south deep water boxes; the deep and the surface south boxes are common to the Atlantic and Indo-Pacific Oceans. The Southern Ocean is represented by a surface box, a circumpolar water box, and a bottom "AABW" box.

In order to make a simplified description of the biological cycle, we consider phosphate $\left(\mathrm{PO}_{4}\right)$ as the biolimiting nu- 


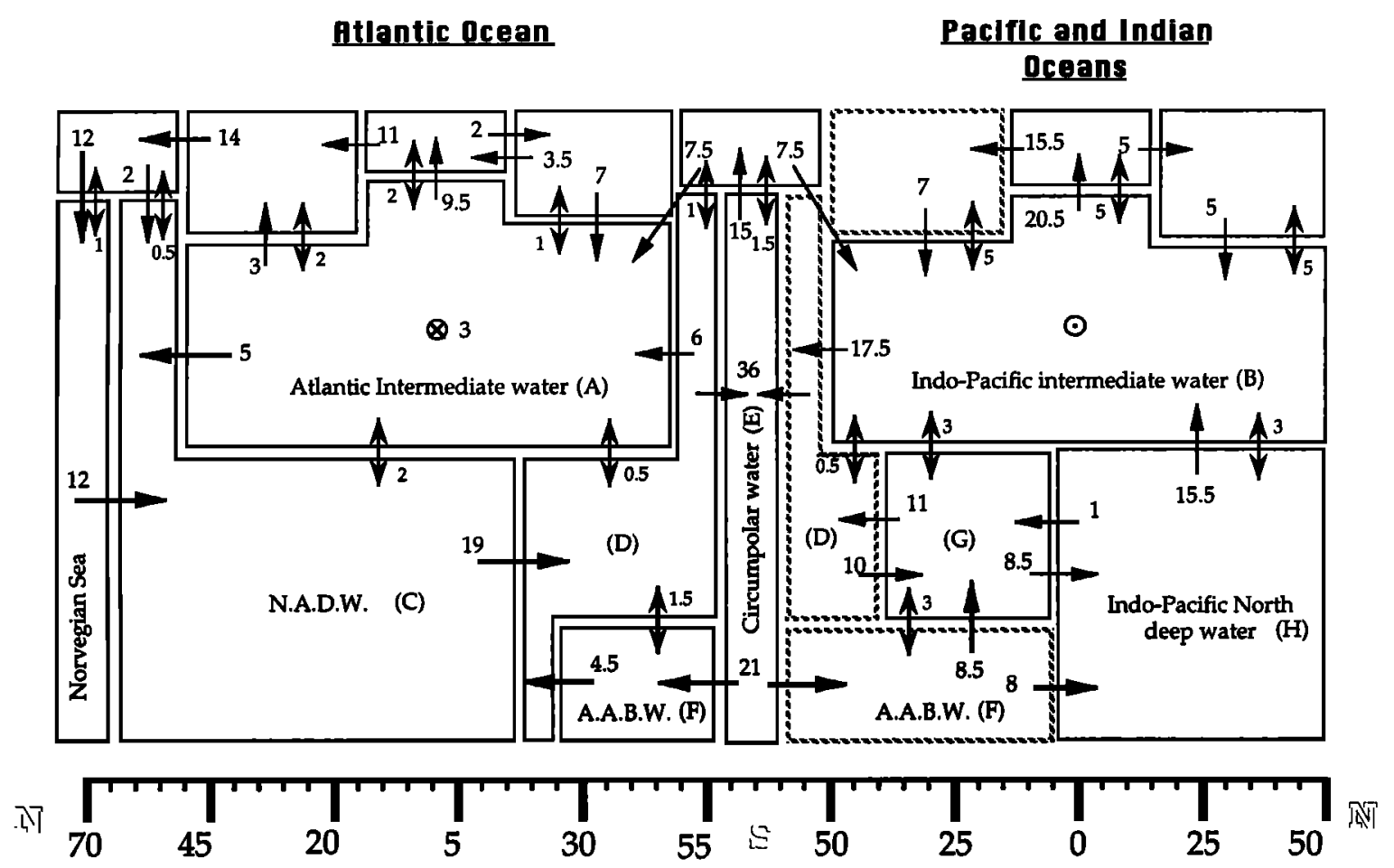

Figure 1. Model boxes. Advective and diffusive fluxes are indicated in sverdrups $\left(10^{6} \mathrm{~m}^{3} \mathrm{~s}^{-1}\right)$ for the modern reference test.

trient. Dissolved phosphorus entering a surface box is nearly all converted into sinking organic matter except for the Southern Ocean surface box, which is not nutrient depleted. The new production carbon flux is fixed to $0.7 \mathrm{~mol} \mathrm{C} \mathrm{m}^{-2} \mathrm{a}^{-1}$ there [Berger et al., 1987; Treguer and Jacques, 1992]. We used the corrected Redfield ratios 1:16:122 for phosphate, nitrate, and carbon in organic matter [Takahashi et al., 1985]. The ratio of organic to carbonate carbon flux is fixed to 5.5 in warm surface water and to 8 in Antarctic surface water where most organic production is associated with siliceous fauna. The term for oxidization rate as a function of depth is taken from Pace et al. [1987]: $85 \%$ of the organic matter that sinks is oxidized in intermediate waters. The regeneration term for carbonate particles is independent of $\mathrm{CO}_{3}^{2}$ concentration in the model. From Watson and Whitfield's [1985] compilation of data and models, we assumed that one third of the inorganic carbon particle flux is dissolved in intermediate waters, the remaining two thirds being regenerated in deeper waters. The ${ }^{13} \mathrm{C}$ fractionation between dissolved organic carbon and organic matter is fixed at $-22 \%$ in warm surface waters and at $-29 \%$ in surface waters of the Southern Ocean [Rau et al, 1989; Fontugne et al, 19911. To compute the ${ }^{14} \mathrm{C}$ distribution, we assume a source of ${ }^{14} \mathrm{C}$ atoms of $12.710^{-6} \mathrm{~mol} \mathrm{~s}-1$ from the atmosphere to the ocean, and each surface box receives an amount proportional to its surface area and exchange coefficient. Given the average phosphate, alkalinity, and carbon of the ocean, we compute the nutrient, carbonate, and carbon isotope distributions at steady state [Michel, 1991]: the ocean circulation, the biological activity, and the mean oceanic ${ }^{13} \mathrm{C} /{ }^{12} \mathrm{C}$ ratio are assumed to have been constant long enough during Holocene intergla- cial or LGM period for the system to arrive at steady state for the $\delta^{13} \mathrm{C}$ distribution.

The modern distributions of total dissolved inorganic carbon, of alkalinity, and of carbon isotopes obtained with the model are displayed on Figure 2 and are compared to the measurements made during the Geochemical Ocean Sections Study (GEOSECS) cruises [Bainbridge, 1980; Broecker et al., 1982; Östlund et al., 1987; Weiss et al., 1982]. The advective fluxes for the modern reference test have been kindly calculated by E. Maier-Reimer using the Hamburg Ocean General Circulation Model (OGCM) [Maier-Reimer and Hasselmann, 1987], we did not do any further tuning. The $\Delta^{14} \mathrm{C}$ distribution is well reproduced by the model. $\Sigma \mathrm{CO}_{2}$ and alkalinity distribution follows the modern features with an increase from the North Atlantic to North Indian and Pacific Oceans through the Southern Ocean, following the "conveyor belt." However, the vertical nutrients fluxes are overestimated because the North Atlantic Deep Water has lower nutrients than those measured, whereas the North Pacific deep water is enriched. The North Indo-Pacific Ocean has also a lower $\delta^{13} \mathrm{C}$ value than that estimated from GEOSECS measurements and NADW has a higher value; as for the $\Sigma \mathrm{CO}_{2}$, the $\delta^{13} \mathrm{C}$ distribution shows the overestimated particulate carbon flux. This total new production excess explains about $0.5 \%$ of the $0.7 \%$ total discrepancy for the $\delta^{13} \mathrm{C}$ result of NADW. Two different factors can be responsible for the remaining $0.2 \%$. First, at the time of the GEOSECS program, this water mass had already been invaded by some fossil fuel $\mathrm{CO}_{2}$. A $28 \mathrm{Gt}$ fossil fuel $\mathrm{CO}_{2}$ invasion at the time of GEOSECS measurements is necessary to produce a $0.2 \%$ decrease for NADW, and this would increase its $\Sigma \mathrm{CO}_{2}$ 

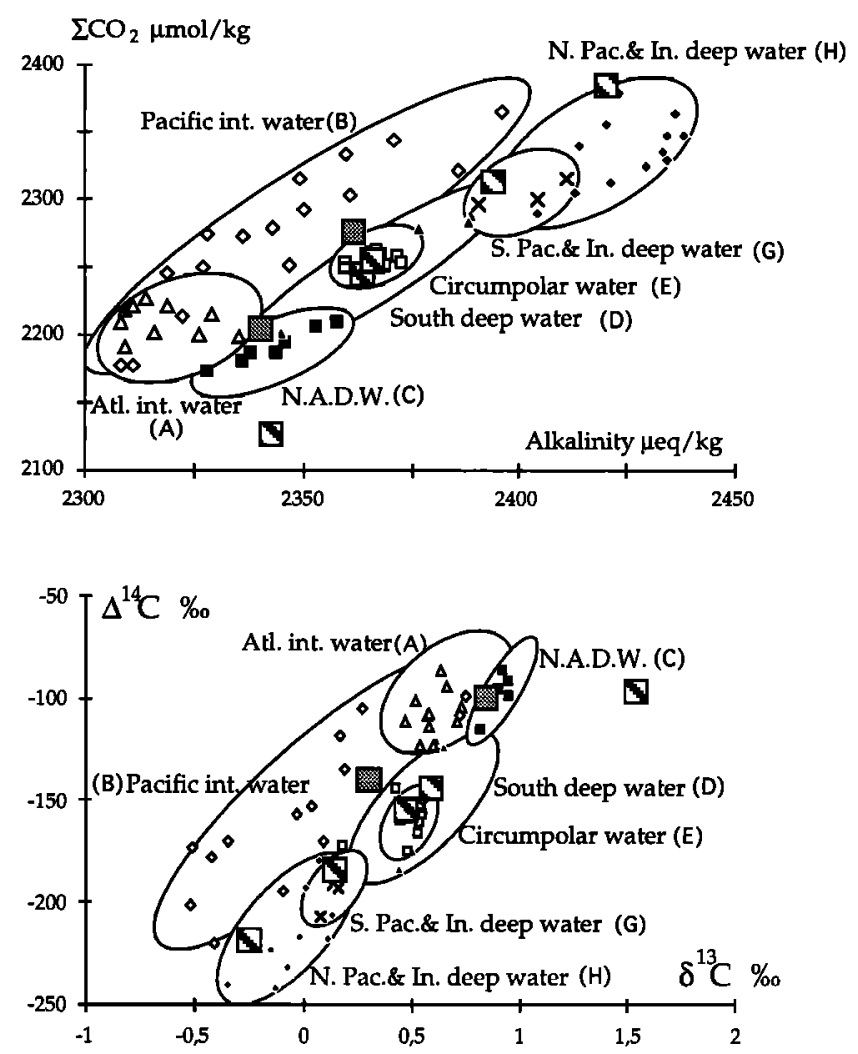

Figure 2. Results for the modern reference test of the model. Small marks are for the Geochemical Ocean Sections Study (GEOSECS) measurements [Östlund et al., 1987; Takahashi et al., 1981]. Symbols are solid squares, North Atlantic Deep Water (NADW); solid triangles, South Atlantic deep water; open triangles, Atlantic intermediate water; crosses, South Indian and Pacific deep waters; solid diamonds, North Indian and Pacific deep waters; open diamonds, Indian and Pacific intermediate waters; open squares, circumpolar water. Larger squares represent the model results: shaded squares for the intermediate boxes and striped squares for the deep boxes.

concentration by $17 \mu \mathrm{mol} \mathrm{kg}{ }^{-1}$. Second, Broecker and MaierReimer [1992] and Charles et al. [1993] have shown that the isotopic fractionation of $\mathrm{CO}_{2}$ molecules associated with airsea exchange produces a -0.2 to $-0.4 \%$ o departure of NADW isotopic composition from the $\delta^{13} \mathrm{C} / \mathrm{PO}_{4}$ line passing through Indian and Pacific deep waters (Figure 3): in the North Atlantic the atmosphere equilibrates its $\mathrm{CO}_{2}$ with warm surface water, so air-sea exchange decreases the $\delta^{13} \mathrm{C}$ of surface water which will form later NADW (their estimation includes the previous factor as they worked with GEOSECS data without any correction for the Suess effect). As our model does not take into account the thermodynamic effect of air-sea exchange, we expect such a departure of the model NADW $\delta^{13} \mathrm{C}$. Another problem with the model is that the alkalinity of Atlantic intermediate waters is too important: there is too much dissolution of carbonate particles in this water mass as model dissolution is not dependent on $\mathrm{CaCO}_{3}$ saturation. Nevertheless, this simple model reproduces the carbon and carbon isotopes distribution well enough to enable us to estimate the influence of oceanic circulation and productivity on LGM $\delta^{13} \mathrm{C}$ distribution.

\section{Model Experiments for an Oceanic Circulation of the Last Glacial Maximum}

In this section we discuss the effects of the LGM's circulation and productivity main features on the $\delta^{13} \mathrm{C}$ distribution. Even if we can consider the glacial $\delta^{13} \mathrm{C}$ values for the intermediate and deep model boxes, as well as the ${ }^{14} \mathrm{C}$ age of Atlantic intermediate and deep waters and Pacific deep water, to be well-known, we have only 12 data points to constrain the model glacial state, whereas 26 parameters are already needed to control the sole advective fluxes. In fact, the model is used here to check whether a given circulation scheme is efficient to reproduce the main features of the LGM's $\delta^{13} \mathrm{C}$ distribution rather than to quantify the glacial circulation.

The three first experiments concern different circulation and productivity hypotheses proposed in previous papers. The first examines intermediate water formation in the North

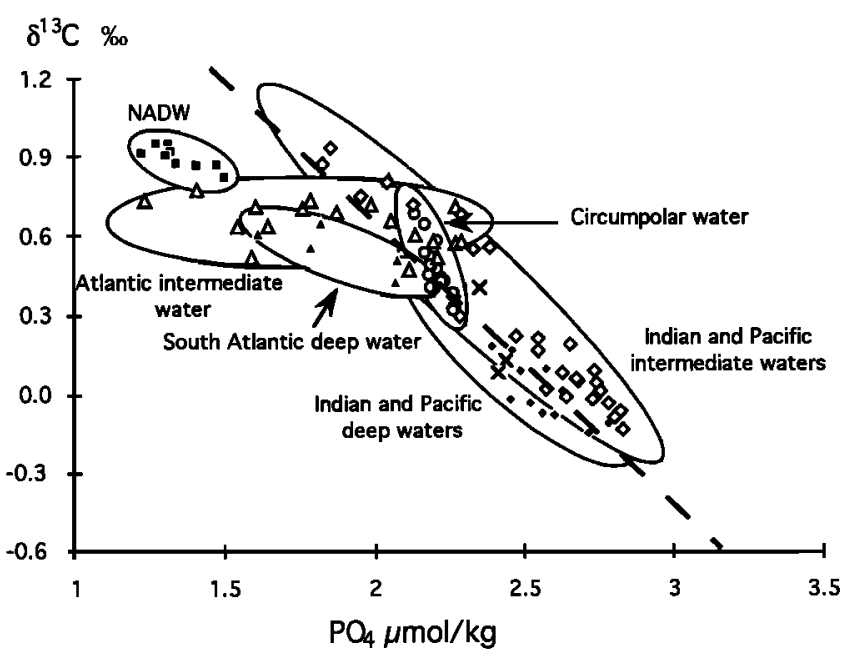

Figure 3. Relation between the $\delta^{13} \mathrm{C}$ of total dissolved inorganic carbon and $\mathrm{PO}_{4}$ measurements of GEOSECS cruises [Bainbridge, 1980; Broecker et al., 1982; Östlund et al., 1987; Weiss et al., 1982]. Symbols are solid squares, NADW water mass; solid triangles, South Atlantic deep water; open triangles, Atlantic intermediate water; solid diamonds, Indian and Pacific deep waters; open diamonds, Indian and Pacific intermediate waters; open circles, circumpolar water. The dashed line corresponds to the $\Delta \delta^{13} \mathrm{C} / \Delta \mathrm{PO}_{4} \approx 1.1$ line passing through deep Indian and Pacific waters. As discussed in the text, the NADW solid squares have a lower $\delta^{13} \mathrm{C}$ than expected if there were no air-sea surface exchange. The Atlantic intermediate water mass has open triangles above and under the line. Open triangles above the line correspond to the southern ones, while open triangles under the line correspond to the northern ones. As for NADW the surface source waters of the North Atlantic intermediate waters are warm, while the surface source waters of South intermediate water are located on the border of the Southern Ocean and are cold. Thus these last surface waters are enriched in ${ }^{13} \mathrm{C}$ by air-sea exchange [Charles $e t$ al., 1993]. The Indian and Pacific intermediate waters have only a southern source so, like the circumpolar water, they are above the line. 
Table 1a. Summary of the $\delta^{13} \mathrm{C}$ Results for the Intermediate and Deep Boxes for the Different Model Experiments

\begin{tabular}{|c|c|c|c|c|c|c|}
\hline \multicolumn{7}{|c|}{ Mean $\delta^{13} \mathrm{C}$ Difference, $\%$} \\
\hline \multirow{2}{*}{$\begin{array}{l}\text { Last Glacial Ma- } \\
\text { ximum - Modem } \\
\text { Benthics }( \pm 0.1)\end{array}$} & \multicolumn{6}{|c|}{ Experiment - Modern Reference Model } \\
\hline & Box & Experiment Ia & Experiment Ib & Experiment Ic & Expenment 2 & Experiment 4 \\
\hline $\begin{array}{r}0.50 \\
0.55 \\
0.10 \\
-0.20 \\
-0.80 \\
-0.60 \\
0.00 \\
0.05 \\
\end{array}$ & $\begin{array}{l}\text { A } \\
\text { B } \\
\text { C } \\
\text { D } \\
\text { E } \\
\text { F } \\
\text { G } \\
\text { H } \\
\end{array}$ & $\begin{array}{r}0.39 \\
0.38 \\
-0.20 \\
-0.09 \\
-0.10 \\
-0.08 \\
-0.03 \\
-0.06 \\
\end{array}$ & $\begin{array}{r}0.05 \\
-0.01 \\
0.04 \\
-0.18 \\
-0.15 \\
-0.07 \\
-0.05 \\
0.10 \\
\end{array}$ & $\begin{array}{r}0.09 \\
0.05 \\
0.30 \\
-0.15 \\
-0.11 \\
0.00 \\
0.01 \\
0.17 \\
\end{array}$ & $\begin{array}{r}0.43 \\
0.26 \\
0.38 \\
-0.14 \\
-0.11 \\
-0.06 \\
-0.11 \\
-0.15\end{array}$ & $\begin{array}{r}0.60 \\
0.53 \\
044 \\
-0.21 \\
-0.68 \\
-0.35 \\
-0.04 \\
0.05 \\
\end{array}$ \\
\hline
\end{tabular}

Experiments Ia, Ib, and Ic show North Atlantic deep Water reduction; experiment 2 shows increased upwellings; experiment 4 shows "glacial circulation".

Atlantic Ocean [Boyle, 1988; Boyle and Keigwin, 1987; Labeyrie et al., 1992] linked with reduced NADW formation [Duplessy et al., 1980; Streeter and Shackleton, 1979]. The second concerns the enhanced mixing of surface and intermediate waters [Arrhenius, 1952; Boyle, 1986], and the third considers an increase of the Southern Ocean surface productivity [Keir, 1990]. In a fourth experiment we proposed an ocean circulation scheme that is compatible with the LGM $\delta^{13} \mathrm{C}$ distribution. It involves the formation of deep water of Subantarctic Mode type filling the Atlantic, Indian, and Pacific basins. For the different model experiments, a summary of the intermediate and deep boxes carbon isotopic composition is given in Tables $1 \mathrm{a}$ and $1 \mathrm{~b}$.

\section{Experiment 1: Reduction of NADW Formation}

The water fluxes used for this experiment (Figure 4.a) are linked to lower NADW production, reduced to one third of the model modern reference. In the North Atlantic, intermediate water formation tends to replace the deep water formation. A decrease of the deep water ventilation follows the decrease of NADW formation, with the return path occurring mostly through intermediate waters.

In this first experiment (1a) the boxes have the modern reference shape. In Figure 4.b the results are given for model boxes similar to the modern reference case. The $\delta^{13} \mathrm{C}$ diffe- rence between this experiment and the modern reference one is indicated for intermediate water and deep water of the two model basins. On the same graph is drawn the difference between LGM and Holocene $\delta^{13} \mathrm{C}$ measurements of benthic foraminifera. In this experiment the intermediate water $\delta^{13} \mathrm{C}$ increases by $0.4 \%$, while it decreases for deep waters, due to the slower advective transfer of nutrients from deep to intermediate water. Also the nutrient content of Atlantic deep water increases a little more than the Pacific one as nutrient accumulation in the Pacific gets slower.

The decrease of the deep water ventilation produces the expected $\delta^{13} \mathrm{C}$ change for intermediate waters [Boyle, 1988; Boyle and Keigwin, 1987] and for the Pacific deep waters. However, we observe neither a sufficient $\delta^{13} \mathrm{C}$ decrease for the deep Atlantic nor the large amplitude decrease that occurred during the LGM in the Southern deep waters.

Broecker et al. [1990], testing a reduced NADW formation with the Pandora model, obtained no significant changes of the phosphate distribution. Similarly, Heinze et al. [1991] did not obtain a different $\delta^{13} \mathrm{C}$ distribution by halving the current velocities of the Hamburg Ocean Carbon Model. In both cases the decrease of NADW formation is followed by a similar decrease of equatorial upwelling. This leads to a decrease of the nutrient export from surface to deep water in the form of organic matter which balances the slower transport of nutrients

Table 1b. Summary of ${ }^{14} \mathrm{C}$ Age Results for the Intermediate and Deep Boxes for the Different Model Experiments

\begin{tabular}{|c|c|c|c|c|c|c|}
\hline \multirow{2}{*}{$\begin{array}{l}\text { Last Glacial Ma- } \\
\text { ximum - Modem } \\
\text { (see text) }\end{array}$} & \multicolumn{6}{|c|}{ Experiment - Modern Reference Model } \\
\hline & Box & Experiment Ia & Experiment Ib & Experiment Ic & Experiment 2 & Experiment 4 \\
\hline $\begin{array}{c}\text { Atlantic Ocean } \\
300 \\
-120 \\
\text { Pacific Ocean } \\
310 \\
-330 \\
\end{array}$ & $\begin{array}{l}\text { C } \\
\text { D } \\
\text { A } \\
\text { G } \\
\text { H } \\
\text { B }\end{array}$ & $\begin{array}{r}278 \\
276 \\
38 \\
417 \\
526 \\
95 \\
\end{array}$ & $\begin{array}{r}311 \\
153 \\
93 \\
125 \\
167 \\
81 \\
\end{array}$ & $\begin{array}{r}105 \\
170 \\
62 \\
217 \\
253 \\
88\end{array}$ & $\begin{array}{r}-2 \\
-55 \\
-149 \\
-106 \\
-83 \\
-283 \\
\end{array}$ & $\begin{array}{r}91 \\
494 \\
-114 \\
323 \\
180 \\
-320 \\
\end{array}$ \\
\hline
\end{tabular}

On the left are the ${ }^{14} \mathrm{C}$ LGM-Modern age difference for benthic foraminifera (age relative to planktonic foramınifera. See text). 

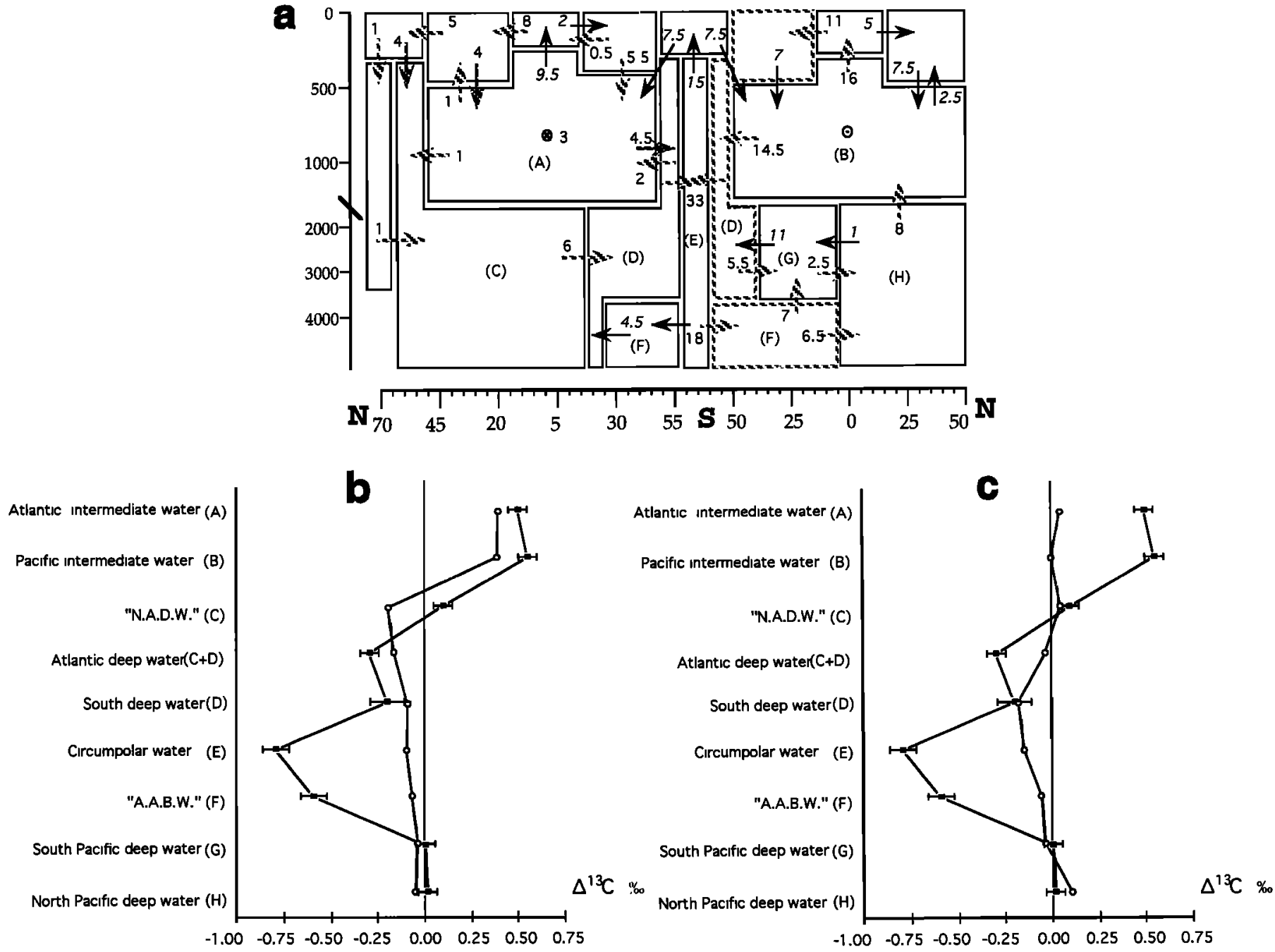

Figure 4. (a) Test 1. Reduction of the deep water formation in the North Atlantic. Heavy striped arrows represent increased fluxes; light ones represent decreased fluxes. Solid arrows are for fluxes similar to the modern reference case. (b) Test 1a. Open circles are model results expressed as the difference $\left(\Delta^{13} \mathrm{C}\right)$ between the $\delta^{13} \mathrm{C}$ values obtained for this test and the values of the modern reference case. Error bars represent Cibicides LGM-Holocene value, with the uncertainty on this difference, to which we added $0.4 \%$. Here, $0.4 \% o$ is the mean oceanic change between LGM and Holocene that we have recalculated with all the cores used in this paper; we found $\mathbf{0 . 4 1 \%}$ o for this difference for a balanced average with the volume and $\Sigma \mathrm{CO}_{2}$ concentration of the different water masses, to be compared to the $0.35 \%$ by Duplessy et al . [1988] and the $0.4 \%$ estimate of Curry et al. [1988], who considered deep waters. The error due to changes of the $\Sigma \mathrm{CO}_{2}$ distribution might produce an oceanic change higher by $0.05 \%$. (c) Test 1 b. Model results are for the same fluxes as in Figure 4a but with intermediate boxes extended to $2000 \mathrm{~m}$ depth. (d) Test 1c. Model fluxes and results for a decrease of the deep water formation in the North Atlantic with the corresponding retreat of the north deep box north to $30^{\circ} \mathrm{N}$ are shown.

from deep waters through reduced ventilation. Nutrients and $\delta^{13} \mathrm{C}$ distributions depend more on the pattern of the circulation than on its strength.

In a second experiment (1b) the intermediate box depth increases down to $2000 \mathrm{~m}$, to be compared to the $1200 \mathrm{~m}$ depth in the previous experiment, corresponding to the large LGM $\delta^{13} \mathrm{C}$ and $\delta^{18} \mathrm{O}$ gradients located at $2000 \mathrm{~m}$ depth [Boyle and Keigwin, 1987; Duplessy et al., 1988; Kallel et al., 1988; Labeyrie et al., 1991; Oppo and Fairbanks, 1987; Zahn et al., 1987].
For the same circulation pattern as in the first experiment, we show on Figure 4.c the model $\delta^{13} \mathrm{C}$ distribution when the intermediate water boxes are extended to $2000 \mathrm{~m}$ depth.

This model box shape produces a very different distribution of $\delta^{13} \mathrm{C}$ values. Because intermediate waters are deeper, they receive more organic matter to the detriment of deep waters and that compensates for the slowing down of nutrient transport by the circulation. Therefore the $\delta^{13} \mathrm{C}$ distribution is almost the same in this case as the modern reference distribution. We will keep this shape of model box for the 

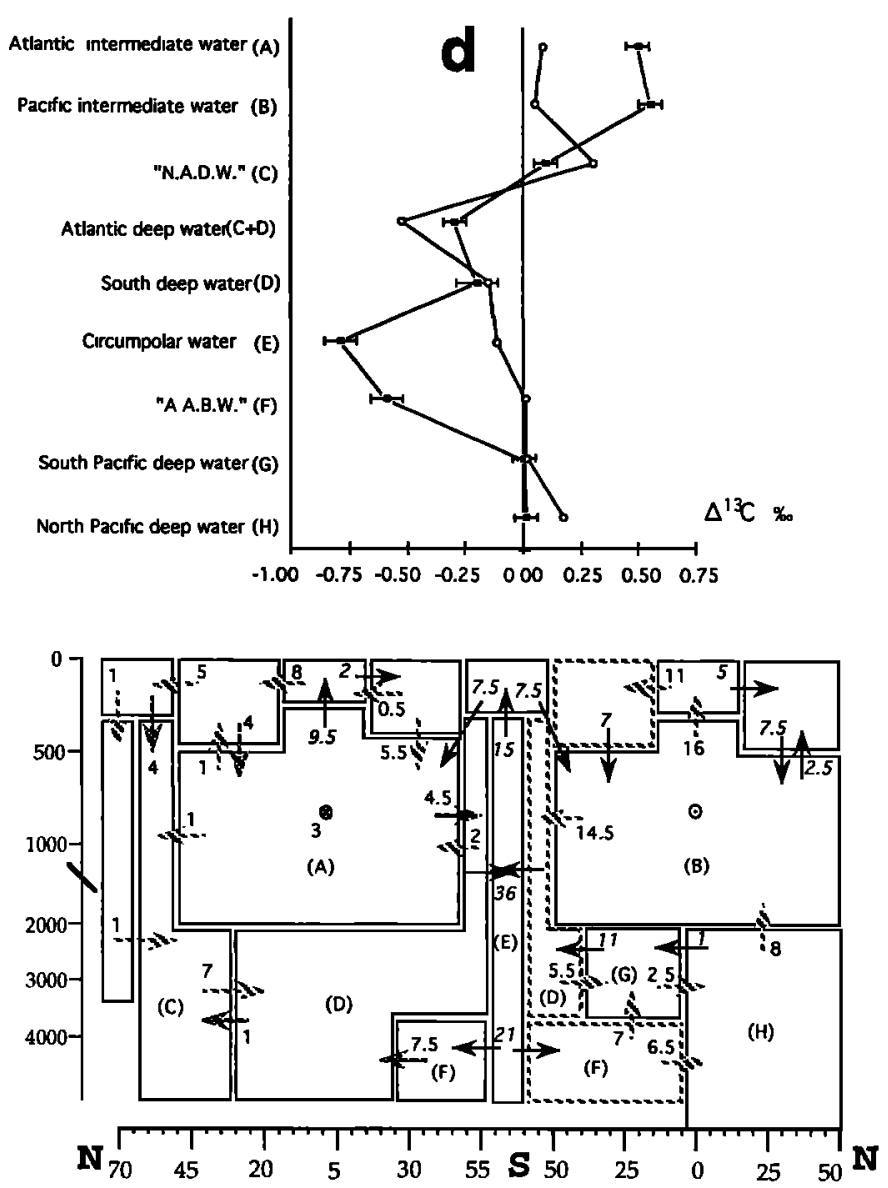

Figure 4. (continued)

next experiments as it represents better the glacial water masses as indicated by sediment core data.

In a third experiment (1c) we used a glacial shape of Atlantic deep boxes. The Atlantic deep water boxes also needed to be changed as the northern component influence is confined to northern latitudes. Now, for "glacial" experiments, the deep South Atlantic box extends to $40^{\circ} \mathrm{N}$. With this new shape of Atlantic deep water boxes and a circulation similar to the one used in previous experiments, the main change for $\delta^{13} \mathrm{C}$ values, when compared to the last experiment, is an increase of $0.25 \%$ for the North Atlantic deep water box (Figure 4.d): it receives less nutrient from organic matter oxidization as it is shortened. The other box concentrations show little change, but the effect for the deep Atlantic Ocean is a large $\delta^{13} \mathrm{C}$ decrease of $-0.5 \%$ as it is now represented mostly by the southern box instead of the northern one.

Reduced deep water ventilation, associated with the changes of box shapes corresponding to the LGM period, produces the expected $\delta^{13} \mathrm{C}$ decrease only for the deep Atlantic. The larger decrease in the Southern Ocean and the increase in intermediate waters are not seen.

\section{Experiment 2: Increase of Intermediate and Surface Waters Mixing}

To reproduce the high $\delta^{13} \mathrm{C}$ value of intermediate waters during the LGM, we tested, as Boyle [1986] proposed, a two- fold increase in the rate of equatorial upwelling. It is associated with an increase of intermediate water formation at the subtropical convergence. The model boxes are of "glacial" type, and the deep circulation is reduced as in the previous experiments. The fluxes and the $\delta^{13} \mathrm{C}$ results are shown on Figure 5.

The productivity increase that follows induces an accumulation of nutrients in deeper waters to the detriment of intermediate waters. More than a twofold increase of equatorial upwelling is required to produce the observed $\delta^{13} \mathrm{C}$ change for intermediate waters.

Compared to the previous experiment, $\delta^{13} \mathrm{C}$ decreases in all deep boxes. The largest change $(-0.30 \%)$ is for North Pacific deep water where nutrients are stored due to the deep circulation pattern. The $\delta^{13} \mathrm{C}$ distribution in this experiment looks more like the LGM distribution, the main difference being in the Southern Ocean. There, the striking low values shown by benthic foraminifera are not reproduced.

\section{Experiment 3: Increase of the Southern Ocean Surface Productivity}

Keir [1990] proposed that the very low values of the Southern Ocean benthic foraminifera originate from an increase of the ratio "productivity over upwelling" in Southern Ocean surface water. However, studies of biogenic silica in Southern Ocean sediments show that even if the productivity was very different from one site to another (probably depen-
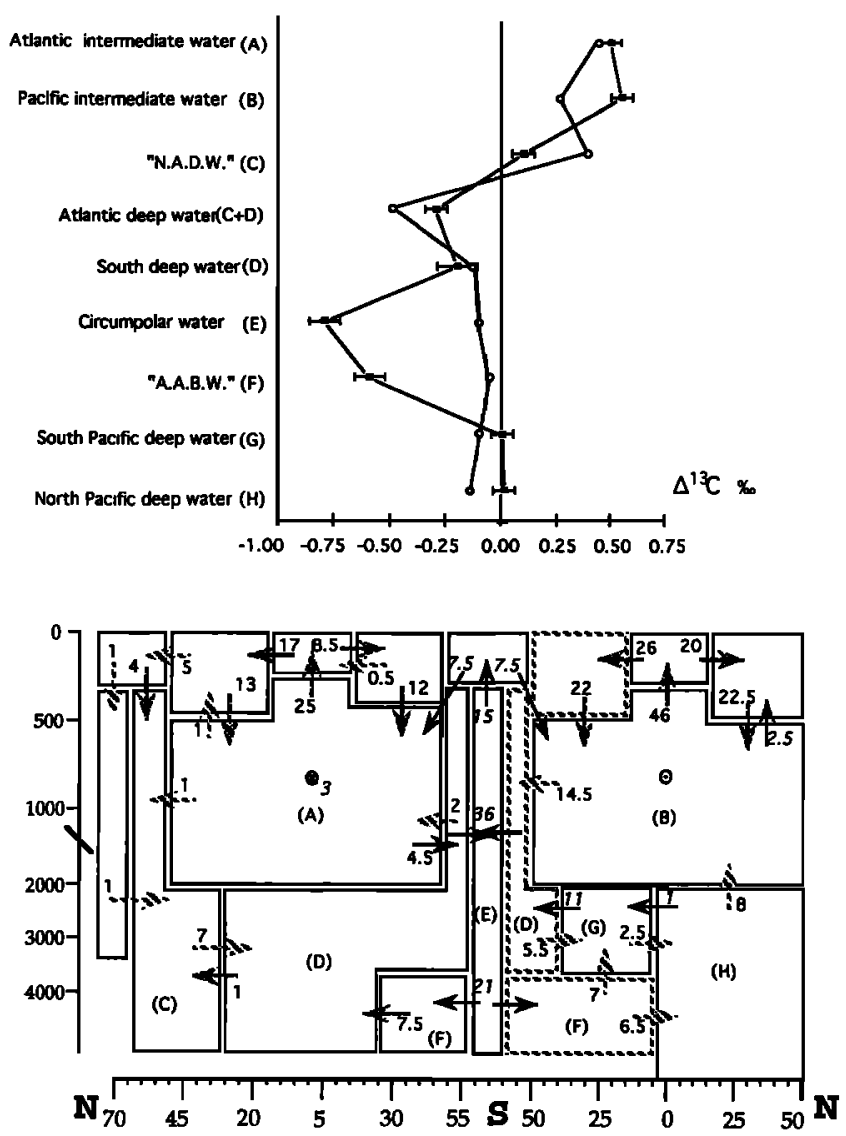

Figure 5. Test 2. Model fluxes and results for enhanced equatorial upwellings are shown. For the description of the symbols, see Figures $4 a$ and $b$. 


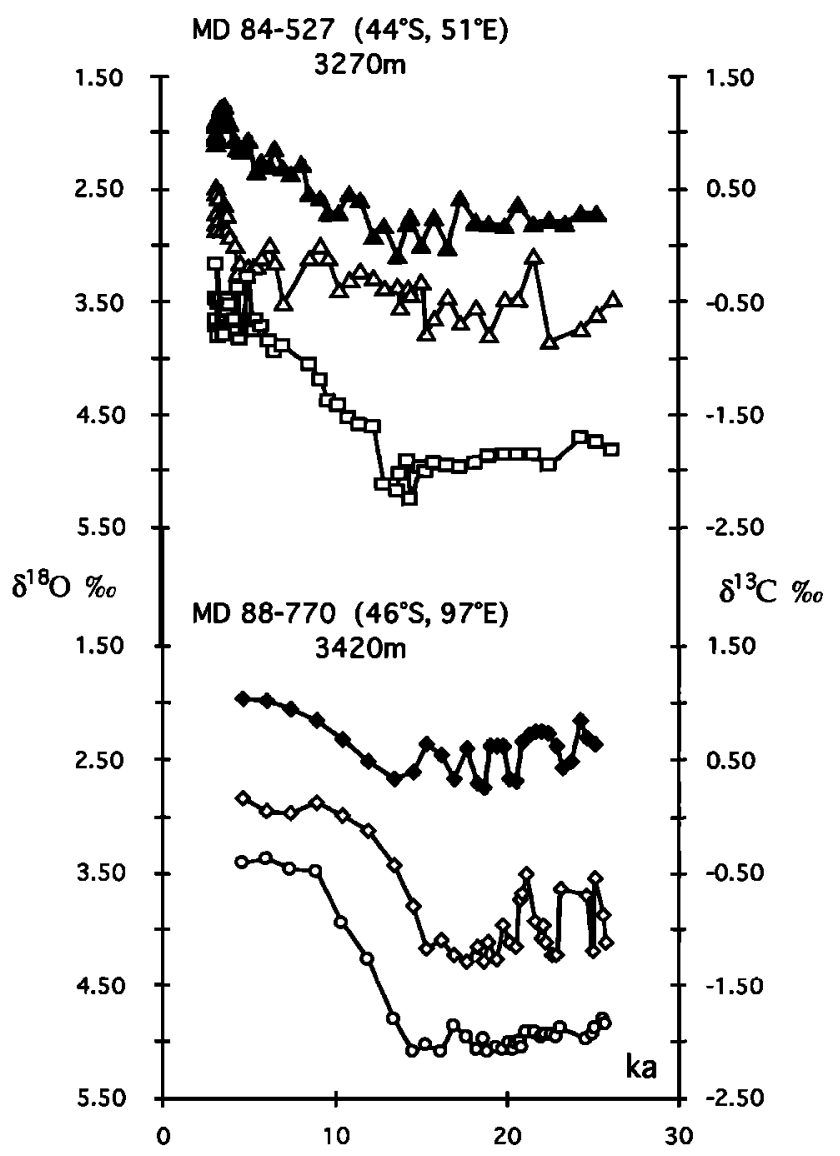

Figure 6. The $\delta^{18} \mathrm{O}$ and $\delta^{13} \mathrm{C}$ records of the benthic foraminifera and $\delta^{13} \mathrm{C}$ record of planktonic foraminifera for the cores MD 84-527 $\left(43^{\circ} 48 \mathrm{~S}, 51^{\circ} 19 \mathrm{E}, 3269 \mathrm{~m}\right)$ [Labeyrie et al., 1986] and MD88-770 (46. $\left.01 \mathrm{~S}, 96^{\circ} 28 \mathrm{E}, 3290 \mathrm{~m}\right)$ [Labeyrie et al., Hydrological changes of the Southern Ocean (South-east Indian sector) over the last $230 \mathrm{kyrs}$, submitted to Paleoceanography]. Open circles and open squares are Cibicoides $\delta^{18} \mathrm{O}$ values for cores MD 88-770 and MD 84-527, respectively. Open diamonds and open triangles are Cibicoides $\delta^{13} \mathrm{C}$ values for cores MD 88-770 and MD 84-527, respectively. Solid diamonds and solid triangles are Pachyderma $\delta^{13} \mathrm{C}$ values for cores MD 88-770 and MD 84527, respectively.

ding on ice cover, ocean surface stratification, etc.), the total Southern Ocean productivity might have been lower or close to the present one during the last glaciation [Bareille, 1991; Mortlock et al., 1991]. Thus a very low mixing rate between deep and surface Antarctic waters would be required to obtain higher ${ }^{13} \mathrm{C} /{ }^{12} \mathrm{C}$ ratio for surface waters. In any case the difference between planktonic and benthic foraminifera $\delta^{13} \mathrm{C}$ would follow the ratio "net production over upwelling." Yet, as for the benthic $\delta^{13} \mathrm{C}$, the $N$. pachyderma $\delta^{13} \mathrm{C}$ values were lower during LGM [Labeyrie and Duplessy, 1985; Charles and Fairbanks, 1990; Mortlock et al., 1991]. In order to get an upper estimate of the effect of an increase of the ratio "productivity over upwelling" in Southern Ocean surface water on the deep Southern Ocean $\delta^{13} \mathrm{C}$, we used a core for which the planktonic isotopic record shows a lower difference between LGM and Holocene than that observed on other locations
(Figure 6). In core MD 88-770, the isotopic record of planktonic foraminifera $N$. pachyderma increases by $0.5 \%$ from LGM to Holocene $(+0.5$ and $+1 \%$, respectively). The benthic foraminifera record shows a larger increase from -1.05 to $0.35 \%$, so the planktonic-benthic difference is $1.55 \%$ during the LGM, and it decreases to $0.65 \%$ for the Holocene period. Considering that the $\delta^{13} \mathrm{C}$ variations of the records are due to factors internal to the Southern Ocean and assuming that the system reaches equilibrium for each stage, we can write the variation of the ratio "net production over upwelling" in the Antarctic considering a two-box (surface and deep boxes) model:

$$
\delta^{13} \mathrm{C}_{\text {surface }}-\delta^{13} \mathrm{C}_{\text {deep }}=-\Phi^{13} \varepsilon_{\text {org }} /\left(\Sigma \mathrm{CO}_{2 \text { deep }} * \text { Flow }\right)
$$

where $\Phi$ is the organic carbon flux of the net production, ${ }^{13} \varepsilon_{\text {org }}$ the fractionation coefficient for the organic matter, and Flow the water mixing between the two boxes. The change of the planktonic-benthic $\delta^{13} \mathrm{C}$ difference is almost proportional to the change of the (net production)/upwelling ratio. This ratio should have been 2.5 higher during the glacial to produce the observed variation of the planktonic-benthic difference between LGM and Holocene. The effect on the deep box $\delta^{13} \mathrm{C}$ from LGM to Holocene can be written as

$$
\begin{aligned}
& \left(\delta^{13} C_{\text {LGM }}-\delta^{13} C_{\text {Holocene }}\right)_{\text {deep }} *\left(1+V_{\text {ol }} l_{\text {deep }} * \Sigma C O_{2 \text { deep }}\right. \\
& \left./ V_{\text {ol }}{ }_{\text {surf }} * \Sigma \mathrm{CO}_{2 \text { surf }}\right)_{\text {Holocene }} \approx\left(\delta^{13} C_{\text {deep }}-\delta^{13} C_{\text {surface }}\right)_{L G M} \\
& -\left(\delta^{13} C_{\text {deep }}-\delta^{13} C_{\text {surface }}\right)_{\text {Holocene }}
\end{aligned}
$$

where $\mathrm{Vol}_{\text {surf }}$ and $\mathrm{Vol}_{\text {deep }}$ represent the volume of the surface and deep boxes. Taking $200 \mathrm{~m}$ depth for the surface box and 2160 and $2260 \mu \mathrm{mol} \mathrm{kg} \mathrm{kg}^{-1}$ for the surface and deep box $\Sigma \mathrm{CO}_{2}$ concentrations, respectively, we found that the effect of a 2.5 increase of the ratio "net production over upwelling" produces a decrease of deep box $\delta^{13} \mathrm{C}$ of about $0.05 \%$. So, from the observed LGM - Holocene benthic $\delta^{13} \mathrm{C}$ difference of $-1.55 \%$, only $-0.05 \%$ can be explained by this mechanism and this is a maximum estimate. Other mechanisms acting on both Southern deep and surface waters have to be considered.

\section{Experiment 4: Deep Water Subantarctic Source}

The previous model experiments produce some of the features of the $\delta^{13} \mathrm{C}$ distribution observed during the LGM for benthic foraminifera: intermediate waters have higher values than during the Holocene, Atlantic deep water has a lower $\delta^{13} \mathrm{C}$ value, and the Pacific deep waters show little change. A map of the $\delta^{13} \mathrm{C}$ values from sediment core located between 2500 and $3500 \mathrm{~m}$ depth is shown for modern and LGM periods on Figure 7.

The major problem to be resolved is to find a deep circulation pattern that produces very low $\delta^{13} \mathrm{C}$ values in the Southern Ocean and yet allows Pacific deep waters to keep the rather high $\delta^{13} \mathrm{C}$ values. During the LGM, Pacific deep waters had higher $\delta^{13} \mathrm{C}$ values than the Southern Ocean; it is therefore not possible to consider southern deep water as a source for Pacific deep waters during glacial time as is the case nowadays. Another deep water source has to be found to fill the Pacific basin.

North Pacific deep water formation has been excluded in view of new foraminifera $\delta^{18} \mathrm{O}$ and $\delta^{13} \mathrm{C}$ data from east and 

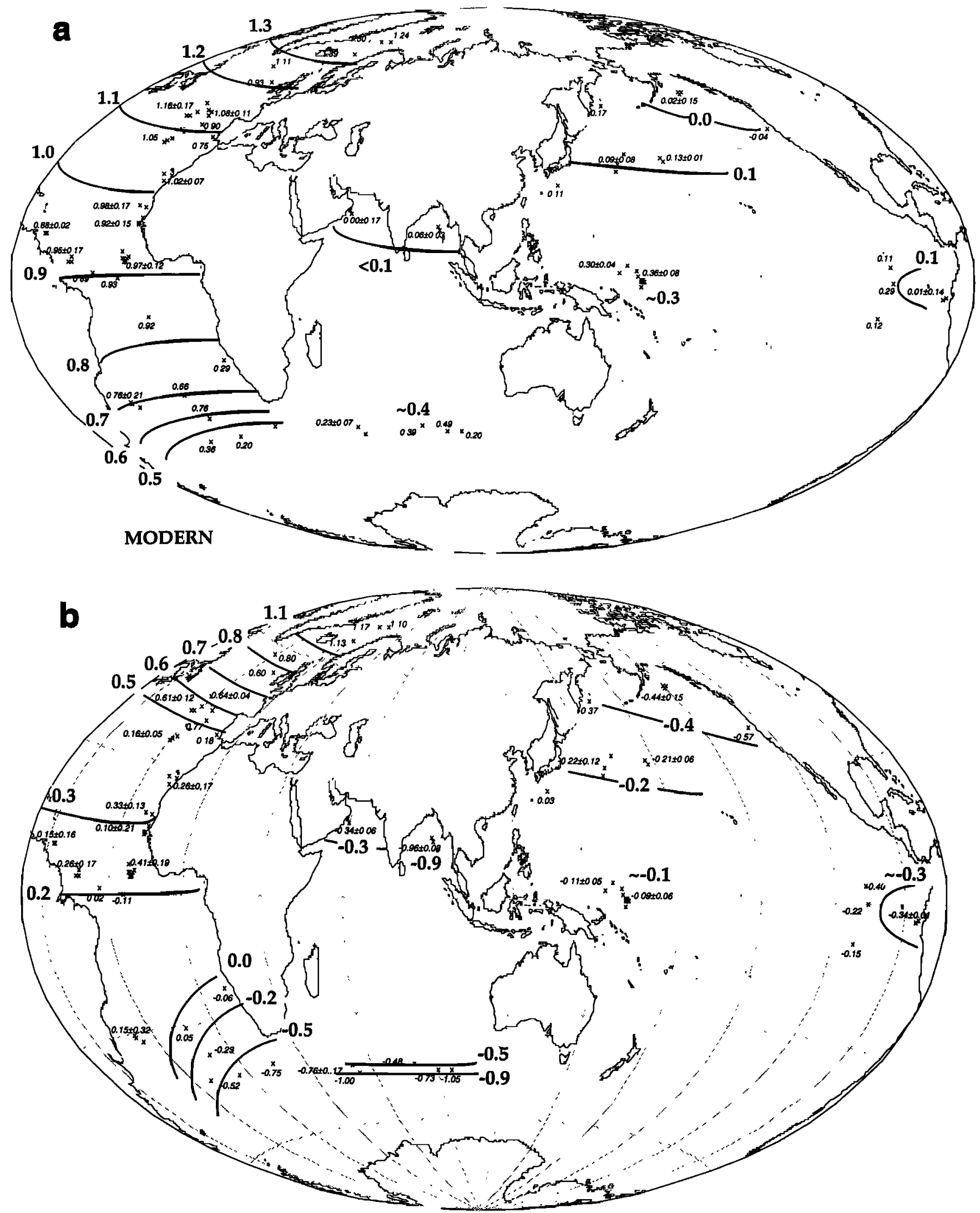

Figure 7. Map of the Cibicides $\delta^{13} \mathrm{C}$ values for the deep waters (around $3000 \mathrm{~m}$ depth): (a) Holocene; (b) LGM. The data are collected from Charles and Fairbanks [1992], Curry et al. [1988], Duplessy et al. [1988], Herguera et al. [1992], Oppo and Fairbanks [1990] and Zahn et al. [1991]. 
west North Pacific sites [Keigwin, 1987; Zahn et al., 1991]. In fact, glacial North Pacific $\delta^{13} \mathrm{C}$ values are lower than equatorial ones (Figure $7 \mathrm{~b}$ ); this indicates that deep water did flow northward during glacial time [Michel, 1991; Zahn et al., 1991]. The Pacific deep water source should be in the western South Pacific because the $\delta^{13} \mathrm{C}$ values are apparently higher on that side.

In the deep Atlantic, the $\delta^{13} \mathrm{C}$ values decrease southward on the LGM map as in the modern distribution. However, they show two steep gradients. The first, between 30 and $45^{\circ}$ South, is much steeper than in the modern distribution. The second gradient, northward of $30^{\circ} \mathrm{N}$, marks the border between deep water originating in the North Atlantic and another component originating in the South Atlantic, near the steepest gradient.

Deep water formation along the Subantarctic convergence, at the tip of South America, flowing northward, would explain the steep $\delta^{13} \mathrm{C}$ gradient in the deep South Atlantic. Similarly, deep water formation around New Zealand, at the northern edge of the polar front, could be a possible source of Pacific deep waters. Such deep water formation along the north part of the Subantarctic convergence would partially isolate the Southern Ocean; its influence on the Atlantic, Indian, and Pacific basins would be restricted to bottom water at depth greater than $4000 \mathrm{~m}$. It would prevent its low $\delta^{13} \mathrm{C}$ values from spreading to others basins, but it would not produce these low values. To accumulate nutrients, the Southern Ocean needs to be located on one deep end of a water loop, implying for this ocean a deep water component from the east Pacific and east Indian basins.

McCartney [1977] named Subantarctic Mode water, the water mass that originates from the vertical convection taking place along the Subantarctic convergence. Gill and Bryan [1971] and McCartney [1977] showed that these waters, formed just upstream from the Drake Passage, were the source of Antarctic Intermediate Waters. Toggweiler et al. [1989a,b], using the Geophysical Fluid Dynamics Laboratory (GFDL) model, found that such downward motion was concentrated at a few longitudes, near the tips of New Zealand, South America, and Africa, and involves more than intermediate waters. Toggweiler et al. [1989a,b] indicate also that circumpolar water appears to be self ventilated, with only two significant southward deep water flows across the circumpolar region, one south of Australia in the Indian Ocean and the other flowing south-westward along the western side of the East Pacific Ridge.

For experiment 4 , we add this deep circulation pattern to the previous experiments to represent oxygen isotopic chron 2 (Figure 8). The circulation pattern has been choosen to produce the lowest $\delta^{13} \mathrm{C}$ values in the Southern Ocean (boxes 13 and 14), keeping intermediate boxes $\delta^{13} \mathrm{C}$ values in agreement with the data. The $\delta^{13} \mathrm{C}$ results shall be reliable because small variations of the fluxes, around this glacial circulation, produce intermediate and deep $\delta^{13} \mathrm{C}$ changes of less than $0.1 \%$. Deep water formation in the North Atlantic is reduced to one third of the reference experiment, and equatorial upwellings are enhanced by a factor of 2 as in experiment 2. Mixing between intermediate and deep waters occurs mostly through diffusion. The South deep water box of the Atlantic and IndoPacific basins has the southern surface box as its surface water
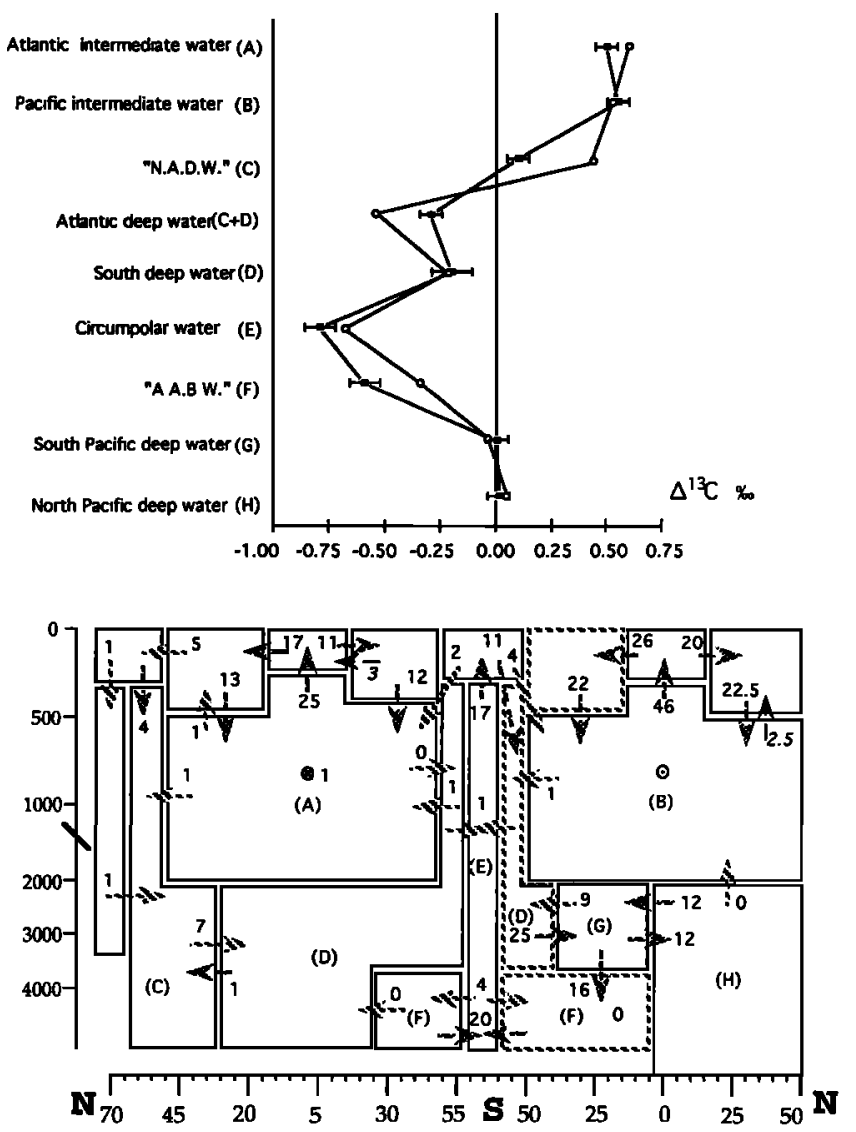

Figure 8. Test 4. Model fluxes and results are for the LGM oceanic circulation. For the description of the symbols, see Figures $4 a$ and $b$.

component, and the deep Southern Ocean is filled with deep water from the Indo-Pacific basins.

The general trend of the glacial $\delta^{13} \mathrm{C}$ distribution is well reproduced by this model (Figure 8 ). The Atlantic and Pacific intermediate waters $\delta^{13} \mathrm{C}$ are about $0.55 \%$ o higher, and Pacific deep water $\delta^{13} \mathrm{C}$ is similar or a little higher than for the modern reference experiment, which is close to the observations. In the North Atlantic the deep box shows a higher $\delta^{13} \mathrm{C}$ which follows the $\delta^{13} \mathrm{C}$ increase of its intermediate and surface sources (which increase by 0.6 and $0.1 \%$ respectively). The $\delta^{13} \mathrm{C}$ of circumpolar water decreases by $0.70 \%$ when compared to the reference experiment and the Southern Ocean bottom water by $0.35 \%$. Though important, this decrease is still smaller than what data indicate. Supplementary decreases of about -0.1 and $-0.25 \%$, respectively, are expected; the ocean circulation we propose for the glacial period reproduces $80 \%$ of the $\delta^{13} \mathrm{C}$ change observed in foraminifera that lived in the circumpolar water.

Our model is mostly based on the possibility that Subantarctic type mode waters were active and deep enough at the LGM to fill the deep ocean basins. The formation of Subantarctic mode waters at deeper layers during the LGM would have been favored by the stronger wind stirring, as this vertical convection is of wind-induced type [Toggweiler et al., 1989a,b]. Also, the salinity of the surface source was higher: 
a preliminary LGM reconstruction shows that surface waters situated on the northern limit of the polar frontal zone had a salinity anomaly larger than $1 \%$ (the salinity anomaly being the LGM - Holocene difference corrected for the mean ocean salinity variation) (J.-C. Duplessy et al., High latitude deep water sources during the last glacial maximum, submitted, 1995), resulting in the presence of dense waters at the northern edge of the southern hemisphere polar frontal zone.

\section{Comparison With $\Delta^{14} \mathrm{C}$ and Lysocline Data}

Few data are available on the ${ }^{14} \mathrm{C} /{ }^{12} \mathrm{C}$ composition of deep and intermediate waters at the LGM. The difference between benthic and planktonic foraminifera $\Delta^{14} \mathrm{C}$ is also of great help for reconstructing the oceanic circulation [Broecker et al., 1984].

One core from the Caribbean sea gives the ${ }^{14} \mathrm{C}$ age of Atlantic intermediate waters [Broecker et al., 1990]. The difference between benthic and planktonic foraminiferal $\Delta^{14} \mathrm{C}$ shows an age of $200 \pm 100$ years for the LGM to be compared to $300 \pm 160$ years during the Holocene. For Pacific intermediate waters, the data of core CH84-14 [Labeyrie et al., 1990] indicate also a younger age at $15 \mathrm{kyr}$ before present than during the Holocene, $370 \pm 100$ and $700 \pm 100$ years respectively. These data suggest that enhanced ventilation of the Pacific intermediate waters lasted throughout oxygen isotopic chronozone 2. For the glacial ocean circulation (experiment 4) the Atlantic intermediate water has an age 115 years younger than that of the modern reference and Pacific intermediate water an age younger by 320 years which is for both oceans very close to what the foraminiferal data indicate. This is obtained by the enhanced mixing of the surface and intermediate boxes corresponding to the enhanced equatorial upwellings and the intermediate water formation at the subtropical convergence in the model.

When considering the ${ }^{14} \mathrm{C}$ production and the oceanic circulation stable, this mechanism is the most efficient one to produce such a reduction of the intermediate-surface water $\Delta^{14} \mathrm{C}$ difference and this can be demonstrated with a simple box model. The warm surface waters are renewed by intermediate waters, so the equilibrium equation is

$$
\begin{aligned}
& \text { Flow }_{\text {is }} * \Sigma \mathrm{CO}_{2 \mathrm{int}} *\left({ }^{14} \mathrm{R}_{\mathrm{int}}-{ }^{14} \mathrm{R}_{\text {surf }}\right)+\varphi_{\text {atoc }} *\left({ }^{14} \mathrm{R}_{\mathrm{atm}}\right. \\
& \text { - } \left.{ }^{14} \mathrm{R}_{\text {surf }}\right)=\lambda * \Sigma \mathrm{CO}_{2 \text { surf }} * \mathrm{Vol}_{\text {surf }} *{ }^{14} \mathrm{R}_{\text {surf }}
\end{aligned}
$$

with Flow $_{\text {is }}$ the water fluxes from intermediate water to surface water and $\varphi_{\text {atoc }}$ the $\mathrm{CO}_{2}$ flux from the atmosphere to the surface and where $\Sigma \mathrm{CO}_{2 \text { int }}$ and $\Sigma \mathrm{CO}_{2 \text { surf }}$ are the $\Sigma \mathrm{CO}_{2}$ concentrations for intermediate and surface waters, respectively; ${ }^{14} R_{\text {surf }},{ }^{14} R_{\text {atm }}$, and ${ }^{14} R_{\text {int }}$ are the ${ }^{14} \mathrm{C} /{ }^{12} \mathrm{C}$ ratio for the surface, the atmosphere, and the intermediate box, respectively, and $\lambda$ is the disintegration constant for ${ }^{14} \mathrm{C}$. We neglect here the isotopic fractionation that occurs during organic matter formation, because the effect on the $\Delta^{14} \mathrm{C}$ distribution is small compare to the effect due to the radioactive decay. For surface waters the radioactive decay term is more than 1 order of magnitude lower because the volume, and consequently the residence time, of the box is small so we can neglect this last term. The second term of (3) $\varphi_{\text {atoc }} *\left({ }^{14} R_{\text {atm }}{ }^{14} R_{\text {surf }}\right)$ can be approximated to the part of the production term of atmospheric ${ }^{14} \mathrm{C}$ reaching the surface box, Prod ${ }^{14} \mathrm{C}$. The age of intermediate waters, age ${ }_{\text {int }}$, corresponding to the benthic-planktonic $\Delta^{14} \mathrm{C}$ difference, is

$$
\text { age }_{\text {int }}=-\left({ }^{14} \mathbf{R}_{\text {int }}-{ }^{14} \mathbf{R}_{\text {surf }}\right) / \lambda *{ }^{14} R_{\text {atm }}
$$

so from (3) and (4), age int $_{\text {is written }}$

$$
\text { age }_{\text {int }}=\left(\operatorname{Prod}^{14} \mathrm{C} / \lambda *{ }^{14} \mathrm{R}_{\mathrm{atm}}\right) * 1 / \mathrm{Flow}_{1 \mathrm{~s}} * \Sigma \mathrm{CO}_{2 \text { int }}
$$

The first part of the second term depends on the gas exchange rate. A global change of the gas exchange rate over the whole ocean surface will result in no ${ }^{14} \mathrm{C}$ difference between surface and deep or intermediate water content for the steady state. In order to estimate the influence of a local increase of the gas exchange rate in the convergence zones, where intermediate waters are formed, we ran the model assuming a twofold increase of the gas exchange rate in the surface source box and no changes in the other surface boxes. The intermediate water ages calculated from the difference between the ${ }^{14} \mathrm{C}$ content of the intermediate water box and the equatorial surface box decrease by $\mathbf{5 0}$ years, which is smaller than the observed decrease. To get an intermediate water age almost twice smaller during the LGM than during the Holocene, the flow from intermediate to surface water had to be enhanced by a factor of two (it is not reasonable to consider a twofold increased $\Sigma \mathrm{CO}_{2}$ concentration of intermediate waters; furthermore, a higher $\Sigma \mathrm{CO}_{2}$ concentration would be linked to a decrease of the intermediate water $\delta^{13} \mathrm{C}$ value). For such a doubled flow the intermediate water $\delta^{13} \mathrm{C}$ does increase by the same order of magnitude as observed during the LGM (Figure 9a, experiment 4).

The glacial oceanic circulation from experiment 4 produces a Pacific deep water age 230 years older than its modern age, in agreement with the $\Delta^{14} \mathrm{C}$ foraminiferal measurements (Figure 9a). Shackleton et al. [1988] found an age older by about 300 years at the LGM than during the Holocene (1520 and 1820 , respectively) for a core extracted at $3210 \mathrm{~m}$ depth in the equatorial Pacific. Broecker et al. [1990] found no difference of age between LGM and the Holocene for a core from Southern China Sea at $2695 \mathrm{~m}$ depth, but this depth is located near the intermediate deep water transition during the LGM, and we know that the age of intermediate water was younger at that time.

In glacial experiment 4 , the age is older by 90 years in the deep North Atlantic, while the $\delta^{13} \mathrm{C}$ is higher (Figure 9a). This deep water, being near its formation site, is fed by intermediate and surface water boxes which had a higher $\delta^{13} \mathrm{C}$ during the glacial maximum period. The $\Delta^{14} \mathrm{C}$ of the deep box is also a little higher, the box having a far smaller volume. Yet, the less active "conveyor belt" produces a larger increase of surface water $\Delta^{14} \mathrm{C}$ (the small boxes undergoing a larger change than the large deep boxes) (Figure $9 b$ ). The difference between the deep and surface water $\Delta^{14} \mathrm{C}$ was more important during the LGM, and the age is older for the North Atlantic deep water. In the south deep box of the model, the water has a 500 years older age during the LGM with a $0.21 \%$ o lower $\delta^{13} \mathrm{C}$. As this box has partly replaced NADW, we obtain for the glacial deep Atlantic a 600 years older age and a $0.54 \%$ lower $\delta^{13} \mathrm{C}$ than for the modern reference experiment. These changes are too large compared to the foraminiferal data: a $\delta^{13} \mathrm{C}$ value lower by $0.3 \%$ and an age older by 300 years [Broecker et al., 1990] would be more appropriate (Figure 9a). This difference 

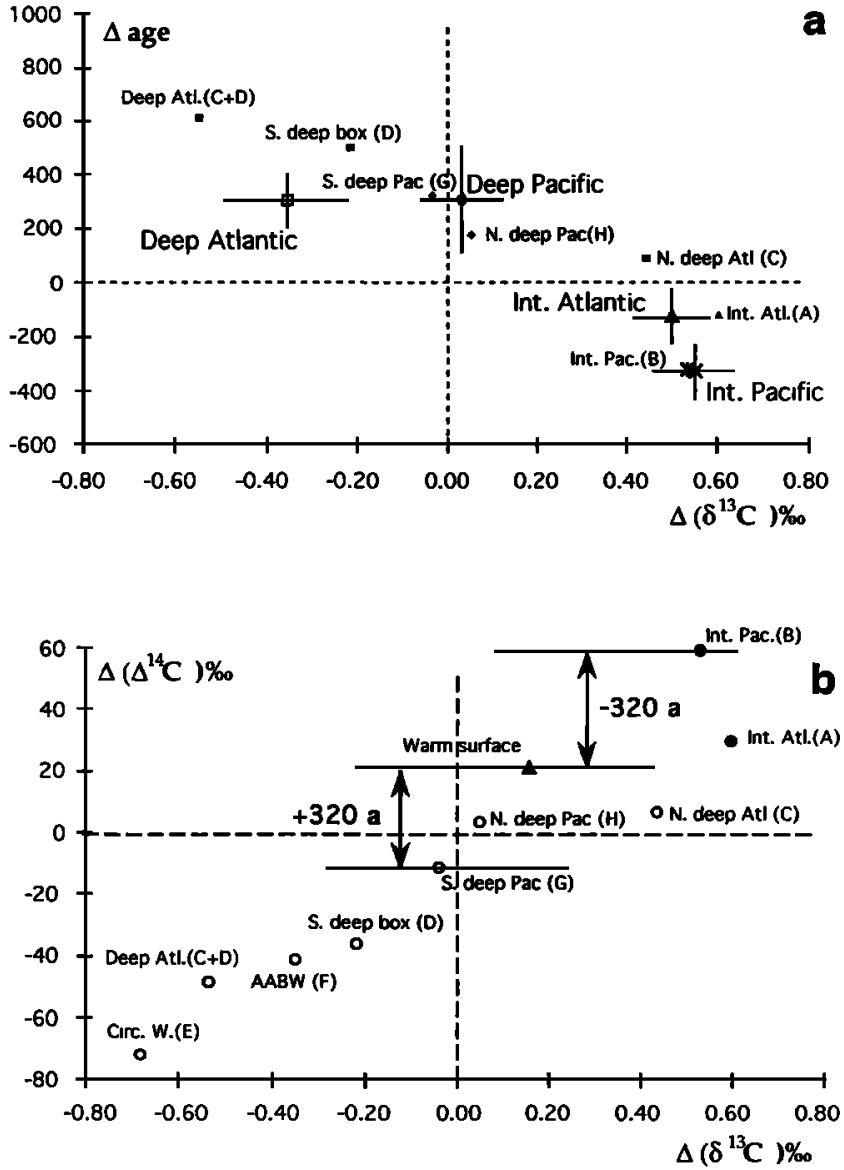

Figure 9. Model results expressed as the difference between test 4 and the modern reference case values. The abscissa is the difference for $\delta^{13} \mathrm{C}$ values $\left(\Delta^{13} \mathrm{C}\right)$. (a) Ordinate values represent the same difference for intermediate and deep box ${ }^{14} \mathrm{C}$ age. Comparison is with the LGM to Holocene difference for foraminifera data (see text). Open symbol with error bars are for the data, solid symbols for model results. (b) Ordinate values represent the difference for intermediate and deep boxes $\Delta^{14} \mathrm{C}$. Solid circles represent the intermediate boxes; open circles represent the deep boxes; solid triangle represent the mean warm surface. The arrows indicate the age of intermediate and deep Pacific waters associated with the difference between above surface water $\Delta^{14} \mathrm{C}$ values and their values.

between the model and the data might be explained by the fact that first the south deep box is common to the Atlantic and Indo-Pacific basins and, second, because this box has for source, in the model, the Southern Ocean surface box instead of the nearby surface water of the Subantarctic Mode water formation site, near the tip of South America. Subantarctic Mode water should also have higher ${ }^{13} \mathrm{C} /{ }^{12} \mathrm{C}$ ratios than what was computed in the model because its surface water source is better equilibrated with the atmosphere. Charles and Fairbanks [1990] indicated that the water located at the Subantarctic front had a $\delta^{13} \mathrm{C}$ higher by up to $1 \%$ o than the surrounding surface waters due to more complete equilibration with the atmosphere.

The $\mathrm{CO}_{3}^{2-}$ distribution, like that of nutrients, is rather different for glacial experiment 4 representing the LGM. For in- termediate waters, an increase of the $\mathrm{CO}_{3}^{2-}$ concentration occurs due to the lower accumulation of nutrients in the intermediate waters and their higher mixing rate with surface water (Figure 10a). It is also noticed that the $\mathrm{CO}_{3}^{2-}$ concentration of Pacific deep water and of the northern Atlantic deep water increases by about 10 and $15 \mu \mathrm{mol} \mathrm{kg}{ }^{-1}$. The largest change when compared to the modern reference occurs for the Atlantic deep water where NADW is replaced during the LGM experiment by a deep water originated in the South, at the Subantarctic convergence (Figure 10a): the $\mathrm{CO}_{3}^{2-}$ concentration decreases by $30 \mu \mathrm{mol} \mathrm{kg}-1$. An important decrease occurs also in the Southern Ocean where nutrients are stored.

To estimate the changes in lysocline depth between the modern reference experiment and the glacial experiment, we used the saturation horizon [Broecker and Takahashi, 1978] In the Atlantic, north of $40^{\circ} \mathrm{N}$, the lysocline depth is even deeper for the glacial experiment than for the modern reference. It might be located around $5500 \mathrm{~m}$ depth. Elsewhere in the deep Atlantic the $30 \mu \mathrm{mol} \mathrm{kg}{ }^{-1}$ decrease of the $\mathrm{CO}_{3}^{2-}$ concentration produces an elevation of the lysocline level up to $3500 \mathrm{~m}$ depth (Figure 10b). This shallowing of the lysocline level is in good agreement with the data: Crowley [1983] and Curry and Lohmann [1985; 1986; 1990] observed that in the north and equatorial part of the Atlantic Ocean, during the LGM, the lysocline was located at shallower depth, around $3500-3800 \mathrm{~m}$, in comparison with its modern depths of about $4900 \mathrm{~m}$ and $4200 \mathrm{~m}$, respectively.

In the Southern Ocean, for experiment 4 , the $\mathrm{CO}_{3}^{2-}$ concentration decrease of $20 \mu \mathrm{mol} \mathrm{kg}-1$ corresponds to a shallowing of up to $1000 \mathrm{~m}$ of the lysocline level. The LGM data indicate a reduction of the carbonate accumulation for this ocean [Bareille, 1991]. However, it might be derived from both a reduction of the production and from a shallowing of the lysocline. No set of cores is available from an extended depth range within a sufficiently small area to separate the influence of both mechanisms and to quantify their effects.

For the Pacific Ocean, experiment 4 produces a deepening of the lysocline depth when compared to the modern reference (Figure 10b). The deepening is very large for the northern part of this ocean: both the intermediate box, where the lysocline is located under modern conditions [Zahn et al., 1990], and the deep box have higher $\mathrm{CO}_{3}^{2-}$ concentration than today, so that the lysocline level is deepened by more than $2000 \mathrm{~m}$, down to $3000 \mathrm{~m}$ depth. In the equatorial Pacific, the lysocline is located in deep waters so the deepening is much smaller, about $500 \mathrm{~m}$. The deepening of the lysocline depth in the Pacific Ocean is also in good agreement with the data. For the northern part, Zahn et al. [1990] consider a possible $2500 \mathrm{~m}$ deepening of the lysocline level at the LGM compared to its modern depth of about $500 \mathrm{~m}$. Farrell and Prell [1989] studied the lysocline and CCD evolution in the equatorial part of this ocean for the last million years; they found a depth of $4800 \mathrm{~m}$ for the lysocline at the LGM to be compared to a depth of 4000-4200 $\mathrm{m}$ during the Holocene. On the other hand, the carbonate compensation depth (CCD) level did not vary much. This reduced transition zone during the LGM might correspond to the transition between the deep water that originated at the Subantarctic convergence and a bottom water from the Southern Ocean. This transition would be much deeper at that time than the modern transition between the Pacific deep water 


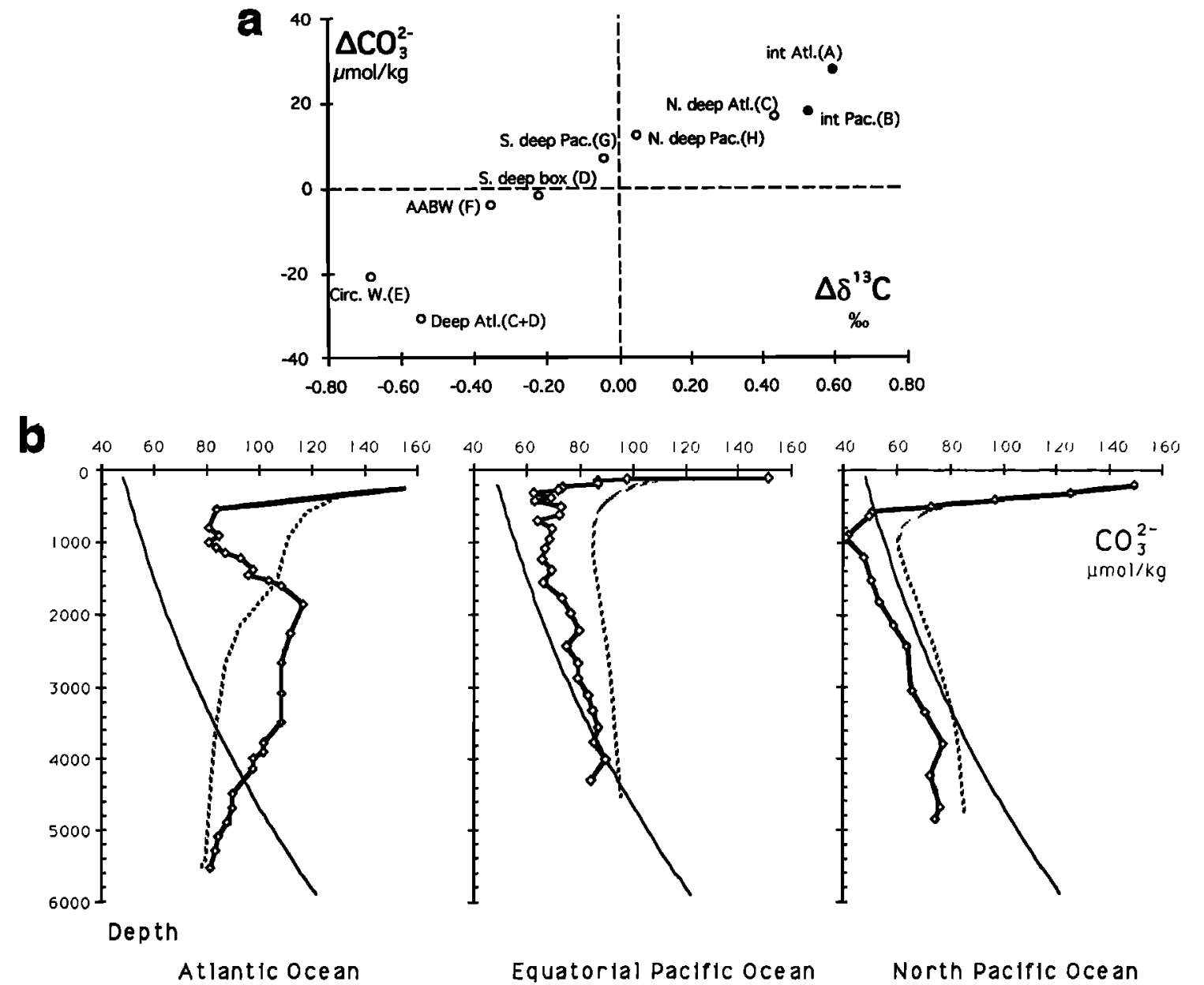

Figure 10. Model results for the LGM (Test 4), $\mathrm{CO}_{3}^{2-}$ concentrations. (a) The results are expressed as the difference between test 4 and the modern reference test results for the $\delta^{13} \mathrm{C}$ of the different boxes in abscissa and their $\mathrm{CO}_{3}^{2-}$ concentrations in ordinate. (b) Depth profiles of the $\mathrm{CO}_{3}^{2-}$ concentration of the Atlantic and Pacific Oceans. Open diamonds are for the GEOSECS measurements [Bainbridge, 1980; Broecker et al., 1982; Weiss et al., 1982] for station $53\left(12^{\circ} \mathrm{S}, 28^{\circ} \mathrm{W}\right)$, station $131\left(5^{\circ} \mathrm{S}, 125^{\circ} \mathrm{W}\right)$, and station $202\left(33^{\circ} \mathrm{N}, 140^{\circ} \mathrm{W}\right)$, from left to right. The solid line represent the depth dependent saturation curve for $\mathrm{CO}_{3}^{2-}$ ions [Broecker and Takahashi, 1978]. The dotted lines represent the depth profile for the results of test 4 using the GEOSECS profiles and the $\mathrm{CO}_{3}^{2-}$ concentration difference of Figure 10a.

and $A A B W$ because of the reduced influence of $A A B W$ during the LGM. In the southern part of the Atlantic, Indian, and Pacific Oceans the lysocline might be located near the transition between the deep waters of Subantarctic origin and the small tongue of bottom water coming from the Southern Ocean.

The glacial experiment 4 produces the general trend observed for the LGM lysocline: the lysocline level is shallower in the Atlantic and Southern Oceans, while the level is deeper in the Pacific Ocean when compared to its Holocene value.

Nevertheless, in the model we do not take into account the equilibrium between input and output of carbonates to and from the ocean. For experiment 4 , an increase of the carbonate particle flux follows the increase of new productivity. To balance this flux increase, particle preservation should be less efficient. This might not be the case because, while preservation is lower in the Atlantic and Southern Oceans, it is much greater in the Pacific Ocean, which covers a large area. However, in the different oceanic basins, during LGM, the ratio "production of carbonate particles over organic matter production" might have been lower than during the Holocene [Bareille, 1991; Curry and Lohmann, 1990; François et al., 1990]. We also do not consider the possible change of the riverine and continental carbonate contributions. However, these changes have a global effect on carbonate preservation but do not change interbasin variations of the lysocline level.

\section{The Thermodynamic Fractionation Effect on the Oceanic $\delta^{13} \mathrm{C}$ Distribution}

The $\delta^{13} \mathrm{C}$ oceanic distribution is also a consequence of the temperature dependence of the isotopic fractionation which occurs during atmosphere surface water exchange: intermediate and deep water isotopic compositions depend on the isotopic 
composition of their surface water source [Broecker and MaierReimer, 1992; Charles et al., 1993]. The $\delta^{13} \mathrm{C} / \mathrm{PO}_{4}$ relationship of these waters is shown on Figure 3 [Broecker and Maier-Reimer, 1992]. Hence the temperature change of surface waters and the ocean-atmosphere exchange intensity at the different latitudes might modify the glacial $\delta^{13} \mathrm{C}$ distribution of the ocean interior. In the model, the atmospheric carbon isotopic composition is computed as a consequence of the surface water $\delta^{13} \mathrm{C}$ so the influence of air-sea exchange on the deep ocean distribution is not taken into account. Only circulation and productivity mechanisms were considered in the previous part. The thermodynamic influence is discussed now.

A reduction of air-sea exchange over the Southern Ocean surface during glacials due to ice cover would decrease its $\delta^{13} \mathrm{C}$ values [Broecker, 1993; Duplessy and Maier-Reimer, 1993; Michel, 1991]. Broecker [1993] proposed that this mechanism was partly responsible of the low values of the deep Southern Ocean to explain the discrepancy between its cadmium and $\delta^{13} \mathrm{C}$ data. The thermodynamic fractionation that occurs during air-sea exchange increases the cold surface water $\delta^{13} \mathrm{C}$ in the Southern Ocean. Broecker and Maier-Reimer [1992] and Charles et al. [1993] showed that nowadays this effect increases the $\delta^{13} \mathrm{C}$ of the deep Southern Ocean by about $0.25 \%$. If no more exchange occurred between atmosphere and surface water in the Southern Ocean, this water mass would have fallen along the mean $\delta^{13} \mathrm{C} / \mathrm{PO}_{4}$ line passing through Pacific and Indian deep waters. The maximum decrease that would result for the deep Southern Ocean $\delta^{13} \mathrm{C}$ values is $0.25 \%$. Such a decrease would explain about one third of the observed decrease for the Antarctic benthic foraminifera $\delta^{13} \mathrm{C}$, and it would not be enough to resolve the cadmium $/ \delta^{13} \mathrm{C}$ discrepancy.

Two mechanisms might have produced the very low $\delta^{13} \mathrm{C}$ values that occurred at the LGM in the benthic isotopic records of the Southern Ocean: a change in the deep ocean circulation and a reduced effect of the thermodynamic air-sea exchange imprint. The first one could explain up to $80 \%$ of the observed decrease (experiment 4 ) and the second up to one third. This last mechanism alters the $\delta^{13} \mathrm{C}$ distribution without changing nutrients, but the circulation change alters both, so the cadmium $/ \delta^{13} \mathrm{C}$ discrepancy for the Southern Ocean is not resolved [Boyle, 1992].

The higher $\delta^{13} \mathrm{C}$ values obtained for the deep North and the intermediate Atlantic might also be explained by the thermodynamic fractionation that occurs during air-sea exchange.

The temperatures of the deep North Atlantic waters were about $4^{\circ} \mathrm{C}$ colder during the LGM [Labeyrie et al. 1987], indicating that their surface source waters were colder and the gas exchange rate might have been higher, due to increased wind, bringing surface waters closer to the thermodynamic equilibrium. However, as today, most of the air-sea exchange might have happened with warmer surface waters before their cooling and sinking [Charles et al., 1993].

Broecker [1993] and Charles et al. [1993] proposed that the temperature modifications of the Atlantic intermediate waters source were responsible for their $\delta^{13} \mathrm{C}$ variations during the LGM. In fact, the temperatures of these intermediate waters was up to $5^{\circ} \mathrm{C}$ lower during the LGM [Kallel, 1988; Labeyrie et al., 1991; Slowey and Curry, 1992], indicating that their surface water source was colder. If the air-sea exchange occurred at lower temperatures, their surface source $\delta^{13} \mathrm{C}$ composition could have been higher by up to $0.6 \%$. However, the cooling of the surface source might have occurred after most of the air-sea exchange. The gas exchange rate might have been higher during LGM, due to increased wind, bringing surface waters and atmosphere closer to the thermodynamic equilibrium. Again the effect on the intermediate waters $\delta^{13} \mathrm{C}$ values depends on its surface source temperature during air-sea exchange, the effect being negative for warm waters and positive for cold waters. It is then rather difficult to estimate the effect of the thermodynamic fractionation on intermediate waters glacial $\delta^{13} \mathrm{C}$ value.

An enhanced mixing between surface and intermediate water is necessary to produce the very young age of intermediate waters observed during the LGM; this increased mixing also accounts for the $\delta^{13} \mathrm{C}$ increase of intermediate waters observed for that time. We therefore believe that this increased mixing must be the main mechanism that has increased the $\delta^{13} \mathrm{C}$ of intermediate waters.

\section{Conclusion}

The LGM $\delta^{13} \mathrm{C}$ distribution derived from benthic foraminifera measurements shows major differences when compared to the modern distribution: higher $\delta^{13} \mathrm{C}$ values for intermediate waters, lower $\delta^{13} \mathrm{C}$ values for deep Atlantic waters, and the lowest $\delta^{13} \mathrm{C}$ values in the Southern Ocean, whereas Pacific deep water $\delta^{13} \mathrm{C}$ values were unchanged.

Different experiments made with a Pandora-Cyclops-like box model allowed us to identify the major oceanic processes that could explain the observed LGM $\delta^{13} \mathrm{C}$ distribution. We propose that a deeper enhanced flux of mode water, in the present area of mode water formation, i.e., near the tips of South America, Africa, and New Zealand [Toggweiler et al., 1989a,b], flowed northward and refilled the Atlantic, Indian, and Pacific basins. The Southern Ocean was then partially isolated and mostly self ventilated, the only deep components being waters of east Indian and east Pacific origin that flew southward along Australia and along the western side of the Eastern Pacific Ridge. The other characteristics of the LGM circulation were a reduced deep water formation in the North Atlantic and a twofold enhanced mixing between surface and intermediate waters. This LGM ocean circulation depends on the ability of the Subantarctic Mode waters to form deep waters more than intermediate waters during the LGM. The LGM ocean circulation proposed here also reproduces correctly the few $\Delta^{14} \mathrm{C}$ data available for the last glacial maximum and is in good agreement with the lysocline data of the LGM.

This circulation modifies as well the nutrients distribution, so it does not resolve the discrepancy between cadmium and $\delta^{13} \mathrm{C}$ data that occurs particularly in the Pacific and Southern Oceans. The changes of surface water temperature have contributed to the LGM $\delta^{13} \mathrm{C}$ features through the thermodynamic fractionation associated with air-sea exchange [Broecker, 1993; Charles et al., 1993], but we do not believe that they may produce the large amplitude of the changes observed for the LGM. 
Acknowledgements. The authors thank the editor, K. Miller, and the referees C. Charles and E. Maier-Reimer for careful reviews, which helped to greatly improve the manuscript. We also thank M. Bender for a preliminar patient review. This work was supported by EEC (Epoch and EU5U CT92-0117), PNEDC, the Mission Scientifique des TAAF, CEA, and CNRS. The foraminiferal isotopic measurements are run by B. Lecoat, J. Antignac, H. Leclaire, and J. Tessier. This is contribution No 1702 of CFR.

\section{References}

Arrhenius, G., Sediment cores from the East Pacific, in Deep-Sea Expedition 1947-1948, pp. 1-228, Gütenborg, Rep. Swed, 1952.

Bainbridge, A.E. (Ed.), GEOSECS Atlantic Expedition: Sections and Profiles, GEOSECS Expedition, vol. 2, 198 pp., U.S. Government Printing Office, Washington, D.C., 1980.

Bareille, G., Les flux d'opale biogène dans le secteur indien de l'océan austral, traceurs de la paleoproductivite et de l'évolution hydrologique au cours du dernier cycle climatique, $P h . D$. thesis, Univ. of Bordeaux, France, 1991.

Berger, W.H., K. Fischer, C. Lai, and C. Wu, Ocean Productivity and organic carbon flux, I, Overview and maps of primary production and export production, SIO Ref. 87-30, Scripps Inst. of Oceanogr., La Jolla, Calif., 1987.

Boyle, E.A., Deep ocean circulation, preformed nutrients, and atmospheric carbon dioxide: Theories and evidence from oceanic sediments, in Mesozoic and Cenozoic Oceans, Geodyn. Ser., vol 15, edited by K.J. Hsï, pp. 49-59, AGU, Washington, D.C., 1986.

Boyle, E.A., The role of vertical chemical fractionation in controlling late Quaternary atmospheric carbon dioxide, J. Geophys. Res., 93. 15,701-15,714, 1988.

Boyle, E.A., Cadmium and $\delta^{13} \mathrm{C}$ paleochemical ocean distributions during the stage 2 glacial maximum, Annu. Rev. Earth Planet. Sci., 20, 245-287, 1992.

Boyle, E.A, and L.D. Keigwin, North Atlantic thermohaline circulation during the past 20,000 years linked to high-latitude surface temperature, Nature, 330, 35-40, 1987.

Broecker, W.S., An oceanographic explanation for the apparent Carbon isotope-Cadmium discordancy in the glacial Antarctic?, Paleoceanography, 8, 137-139, 1993.

Broecker, W.S., and E. Maier-Reimer, The influence of air and sea exchange on the carbon isotope distribution in the sea, Global Biogeochem. Cycles, 6, 315-320, 1992.

Broecker, W.S., and T.-H. Peng, Carbon Cycle: 1985 - Glacial to interglacial changes in the operation of the global carbon cycle, Radiocarbon, 28, 309-327, 1986.

Broecker, W.S., and T. Takahashi, The relationship between lysocline depth and in situ carbonate ion concentration, Deep Sea Res., 25 , 65-95, 1978.

Broecker, W.S., D.W. Spencer, and H. Craig, GEOSECS Pacific Expedition: Sections and Profiles, U.S. Govemment Printing Office, Washington, D.C., 1982.

Broecker, W.S., A. Mix, M. Andree, and H. Oeschger, Radiocarbon measurements on coexisting benthic and planktic foraminifera shells: Potential for reconstructing ocean ventilation times over the past 20,000 years, Nucl. Instrum. Methods Phys. Res., Sect. B, 5 . 331-339, 1984.

Broecker, W.S., T.H. Peng, S. Trumbore, G. Bonani, and W. Wolfli, The distribution of radiocarbon in the glacial ocean, Global Biogeochem. Cycles, 4, 103-117, 1990.

Charles, C.D., and R.G. Fairbanks, Glacial to Interglacial changes in the isotopic gradients of Southern Ocean surface water, in Geological History of the Polar Oceans: Arctic versus Antarctic, Mathematical and Physical Sciences, Vol. 308, edited by U. Bleil and J. Thiede, 519-538, Kluwer Academic, Norwell, Mass., 1990.

Charles, C.D., and R.G. Fairbanks, Evidence from Southern Ocean sediments for the effect of North Atlantic deep-water flux on climate, Nature, 355, 416-419, 1992.

Charles, C.D., J.D. Wright, and R.G. Fairbanks, Thermodynamic influences on the marine carbon isotope record, Paleoceanography, 8, 691-697, 1993.

Crowley, T.J., Calcium-carbonate preservation patterns in the central
North Atlantic during the last 150,000 years, Mar. Geol., 51, 1-14, 1983 .

Curry, W.B., and G.P. Lohmann, Carbon deposition rates and deep water residence time in the equatorial Atlantic Ocean throughout the last 160,000 years, in The Carbon Cycle and Atmospheric $\mathrm{CO}_{2}$ Natural Variations Archean to Present, Geophys. Monogr. Ser., Vol 32, edited by E. Sundquist and W.S. Broecker, pp. 285-301, AGU, Washington, D.C., 1985.

Curry, W.B., and G.P. Lohmann, Late Quatemary carbonate sedimentation at the Sierra Leone Rise (Eastern Equatorial Atlantic), Mar. Geol., 70, 223-250, 1986.

Curry, W.B., and G.P. Lohmann, Reconstructing past particle fluxes in the tropical Atlantic ocean, Paleoceanography, 5, 487-505, 1990.

Curry, W.B., J.-C. Duplessy, L.D. Labeyrie, and N.J. Shackleton, Changes in the distribution of $\delta^{13} \mathrm{C}$ of deep water $\Sigma \mathrm{CO}_{2}$ between the last glaciation and the Holocene, Paleoceanography, 3, 317-341, 1988.

Duplessy, J.-C., and E. Maier-Reimer, Global ocean circulation changes, in Global Changes in the Perspective of the Past, Environmental Sciences Research Report, edited by J.A. Eddy and H. Oeschger, 199-220, John Wiley, New York, 1993.

Duplessy, J.C., J. Moyes, and C. Pujol, Deep water formation in the North Atlantic Ocean during the last ice age, Nature, 286, 479-482, 1980.

Duplessy, J.C., N.J. Shackleton, R.G. Fairbanks, L.D. Labeyrie, D. Oppo, and N. Kallel, Deep water source variations during the last climatic cycle and their impact on the global deepwater circulation, Paleoceanography, 3, 343-360, 1988.

Farrell, J., and $\mathrm{W}{ }_{\mathrm{L}}^{\mathrm{t}}$. Prell, Climatic change and $\mathrm{CaCO}_{3}$ preservation: An 800,000 -year bathymetric reconstruction from the central Equatorial Pacific Ocean, Paleoceanography, 4, 447-466, 1989.

Fontugne, M.R., C. Descolas-Gros, and G. de Billy, The dynamics of $\mathrm{CO}_{2}$ fixation in the Southern Ocean as indicated by carboxylase activities and organic carbon isotopic ratios, Mar. Chem., 35, 371$380,1991$.

François, R., M.P. Bacon, and D.O. Suman, Thorium 230 profiling in deep-sea sediments: High-resolution records of flux and dissolution of carbonate in the equatorial Atlantic ocean during the last 24,000 years, Paleoceanography, 5, 761-787, 1990.

Gill, A.E., and K. Bryan, Effects of geometry on the circulation of a three-dimensional southern-hemisphere ocean model, Deep Sea Res., 18, 685-721, 1971.

Heinze, C., E. Maier-Reimer, and $\mathrm{K}$. Winn, Glacial $\mathrm{pCO}_{2}$ reduction by the world ocean: Experiments with the Hamburg carbon cycle model, Paleoceanography, 6, 395-430, 1991.

Herguera, J.C., E. Jansen, and W.H. Berger, Evidence for a bathyal front at $2000 \mathrm{~m}$ depth in the glacial Pacific, based on a depth transect on Ontong Java Plateau, Paleoceanography, 7, 273-288, 1992.

Kallel, N., Variation de la composition isotopique de l'oxygène et du carbone des foraminifères: Traceur de la circulation océanique pendant le dernier maximum glaciaire et lors de la dernière déglaciation, Ph. D. Thesis, 201pp., Univ. of Paris XI, 1988.

Kallel, N., L.D. Labeyrie, A. Juillet-Leclerc, and J.C. Duplessy, A deep hydrological front between intermediate and deep-water masses in the glacial Indian Ocean, Nature, 333, 651-655, 1988.

Keigwin, L.D., North Pacific deep water formation during the latest glaciation, Nature, 330, 362-364, 1987.

Keir, R.S., On the late Pleistocene Ocean geochemistry and circulation, Paleoceanography, 3, 413-446, 1988.

Keir, R.S., Reconstructing the ocean carbon system variation during the last 150,000 years according to the Antarctic nutrient hypothesis, Paleoceanography, 5, 253-276, 1990.

Labeyrie, L.D., and J.C. Duplessy, Changes in the oceanic ${ }^{13} \mathrm{C} /{ }^{12} \mathrm{C}$ ratio during the last 140,000 years: High-latitude surface records, Palaeogeogr. Palaeoclimatol. Palaeoecol. 50, 217-240, 1985.

Labeyrie, L.D., J.J. Pichon, M. Labracherie, P. Ippolito, J. Duprat, and J.C. Duplessy, Melting history of Antarctica during the past 60,000 years, Nature, 322, 701-706, 1986.

Labeyrie, L.D., J.C. Duplessy, and P.L. Blanc, Variations in mode of formation and temperature of oceanic deep waters over the past 125,000 years, Nature, 327, 477-482, 1987.

Labeyrie, L.D., N. Kallel, M. Arnold, A. Juillet-Leclerc, F. Maitre, J.C. 
Duplessy, and N.J. Shackleton, Variabilité des eaux intermédiaires et profondes dans l'océan Pacifique nord ouest pendant la dernière déglaciation, Oceanol. Acta, 10, 329-339, 1990.

Labeyrie, L.D., A. Juillet-Leclerc, N. Kallel, and P.-L. Blanc, Sea level and oceanic thermohaline circulation: Changes over a glacial/interglacial cycle, in Klimageschichtliche Probleme der letzten 130000 Jahre, Paläoklimaforschung, edited by B. Frenzel, 197-214, Gustav Fischer Verlag, New York, 1991.

Labeyrie, L.D., J.-C. Duplessy, J. Duprat, A. Juillet-Leclerc, J. Moyes, E. Michel, N. Kallel, and N.J. Shackleton, Changes in the vertical structure of the North Atlantic ocean between glacial and modern times, Quat. Sci. Rev., 11, 401-413, 1992.

Mackensen, A., H.-W. Hubberten, T. Bickert, G. Fischer, and D.K. Fütterer, The $\delta^{13} \mathrm{C}$ in benthic foraminiferal tests of Fontbotia Wuellerstorfi (Schwager) relative to the $\delta^{13} \mathrm{C}$ of dissolved inorganic carbon in the Southern Ocean deep water: Implications for glacial ocean circulation models, Paleoceanography, 8, 587-610, 1993.

Maier-Reimer, E., and K. Hasselmann, Transport and storage of $\mathrm{CO}_{2}$ in the ocean - an inorganic ocean circulation carbon cycle model, Clim. Dyn., 2, 63-90, 1987.

McCartney, M.S., Subantarctic mode water, in A Voyage of Discovery, edited by A. Angel, pp. 103-119, Pergamon, Tarrytown, N.Y., 1977.

Michel, E., L'océan au dernier maximum glaciaire: le cycle du carbone et la circulation. Contraintes isotopiques et modélisation, $P h . D$. Thesis, 194pp, Univ. of Paris XI, 1991.

Mortlock, R.A., C.D. Charles, P.N. Froelich, M.A. Zibello, J. Saltzman, J.D. Hays, and L.H. Burckle, Evidence for lower productivity in the Antarctic Ocean during the last deglaciation, Nature, 351, 220-222, 1991.

Oppo, D.W., and R.G. Fairbanks, Variability in the deep and intermediate water circulation of the Atlantic Ocean during the past 25,000 years: Northern Hemisphere modulation of the Southern Ocean, Earth Planet. Sci. Lett., 86, 1-15, 1987.

Oppo, D.W., and R.G. Fairbanks, Atlantic Ocean thermohaline circulation of the last 150,000 years: Relationship to climate and atmospheric $\mathrm{CO}_{2}$, Paleoceanography, 5, 277-288, 1990.

Östlund, H.G., H. Craig, W.S. Broecker, and D. Spencer (Eds.), GEOSECS Atlantic, Pacific, and Indian Ocean Expeditions. Shorebased Data and Graphics, GEOSECS Expedition, vol. 7, 200 pp., U.S. Government Printing Office, Washington D.C., 1987.

Pace, M.L., G.A. Knauer, D.M. Karl, and J.H. Martin, Primary production, new production and vertical flux in the eastern Pacific Ocean, Nature, 325, 803-804, 1987.

Rau, G.H., T. Takahashi, and D.J. Des Marais, Latitudinal variations in plankton $\delta^{13} \mathrm{C}$ : Implications for $\mathrm{CO}_{2}$ and productivity in past oceans, Nature, 341, 516-518, 1989.

Shackleton, N.J., J.C. Duplessy, M. Arnold, P. Maurice, M.A. Hall, and J. Cartlidge, Radiocarbon age of last glacial Pacific deep water. Nature, 335, 708-711, 1988.

Slowey, N.C., and W.B. Curry, Enhanced ventilation of the North
Atlantic subtropical gyre thermocline during the last glaciation, Nature, 358, 665-668, 1992.

Streeter, S.S., and N.J. Shackleton, Paleocirculation of the deep north Atlantic: 150,000-year record of benthic foraminifera and oxygen18, Science, 203, 168-171, 1979.

Takahash1, T., W.S. Broecker, and A.E. Bainbridge, Supplement to the alkalinity and total carbon dioxide concentration in the world oceans, in Carbon Cycle Modelling, SCOPE, edited by B. Bolin, 159. 199, John Wiley, New York, 1981.

Takahashi, T., W.S. Broecker, and S. Langer, Redfield ratio estımates based on chemical data from isopycnal surfaces, J. Geophys. Res, 90, 6907-6924, 1985.

Toggweiler, J.R., K. Dixon, and K. Bryan, Simulations of radiocarbon in a coarse-resolution world ocean model, 1 , Steady state prebomb distributions, J. Geophys. Res., 94, 8217-8242, 1989a.

Toggweiler, J.R., K. Dixon, and K. Bryan, Simulations of radiocarbon in a coarse-resolution world ocean model, 2, Distributions of bombproduced carbon 14, J. Geophys. Res., 94, 8242-8264, $1989 \mathrm{~b}$

Treguer, P., and G. Jacques, Dynamics of nutrient and phytoplancton and cycles of carbon, nitrogen and silicon in the Southern Ocean: A review, Polar Biol., 12, 149-162, 1992.

Watson, A.J., and M. Whitfield, Composition of particles in the global ocean, Deep Sea Res., Part A, 32, 1023-1039, 1985.

Weiss, R.F., W.S. Broecker, H. Craig, and D.W. Spencer, GEOSECS Indian Ocean Expedition: Sections and Profiles, U.S. Government Printing Office, Washington, D.C., 1982.

Zahn, R., M. Sarnthein, and H. Erlenkeuser, Benthic isotope evidence for changes of the Mediterranean Outflow during the late Quaternary, Paleoceanography, 2, 543-559, 1987.

Zahn, R., A. Rushdi, B.D. Bornhold, B. Blaise, N.G. Pisias, and K. Karlın, Carbonate deposition and benthic $\delta^{13} \mathrm{C}$ in the Subarctic Pacific: Implications for changes of the oceanic carbonate system during the past 750,000 years, Earth Planet. Sci. Lett., 103, 116-132, 1990.

Zahn, R., T.F. Pedersen, B.D. Bornhold, and A.C. Mix, Water mass conversion in the glacial Subarctic Pacific $\left(54^{\circ} \mathrm{N}, 148^{\circ} \mathrm{W}\right)$ : Physical constraints and the benthic-planktonic stable isotope record, Paleoceanography, 6, 543-560, 1991

J.C. Duplessy, N. Gorfti, L.D. Labeyrie, and E. Michel, Centre des Faibles Radioactivités, Laboratoire mixte CNRS-CEA, Domaine du CNRS, 91198 Gif/Yvette, cedex, France. (e-mail: Eisabeth.Michel@eole.cfr. cnrs-gif.fr)

M. Labracherie and J.-L. Turon, Département de Géologie et d'Océonagraphie, Université Bordeaux I, 33405 Talence, cedex, France.

(Received July 28, 1994; revised March 21, 1995; accepted March 31, 1995.) 